\title{
Open Market Operations as a Monetary Policy Shock Measure in a Quantitative Business Cycle Model
}

\author{
By Burkhard Heer* and Andreas Schabert $\dagger$ \\ * University of Cologne, Department of Economics, 50923 Cologne, Germany, email: heer@wiso.uni-koeln.de \\ $\dagger$ University of Cologne, Department of Economics, 50923 Cologne, Germany, email: schabert@wiso.uni- \\ koeln.de
}

February 21, 2000

JEL classification: E30; E50; E52;

Keywords: Monetary policy; Financial Intermediation; Open market operations; Business cycles; Price stickiness

\begin{abstract}
:
This paper presents a business cycle analysis of monetary policy shocks measured by disturbances to open market operations, i.e. the ratio of open market papers to non-borrowed reserves. We find empirical evidence for the usefulness of this policy measure, as it predicts significant declines in output, M1 growth, and prices, as well as a significant rise in interest rates after a monetary contraction. We develop a dynamic general equilibrium model with financial intermediation where monetary policy is conducted via open market operations. In accordance with our empirical findings, a monetary tightening leads to a fall in output, monetary aggregates, and factor prices. In contrast to an alternative model specification with money growth shocks, our model with disturbances to open market operations also generates a persistent rise of nominal and real interest rates on securities in response to a monetary contraction. Furthermore, the introduction of staggered prices is demonstrated to improve the model's ability to replicate second moments of empirical time series.
\end{abstract}




\section{Introduction}

Standard monetary business cycle models assume that money supply is exogenous. The growth rate of money supply is usually assumed to follow a stochastic process. Hence, monetary policy is identified by innovations to the growth rate of money, even if the latter is specified as a broad aggregate. Changes in money supply are injected lump sum directly either to the households or to the financial intermediaries. Short-run effects on real activity driven by these nominal transfers are generated by an inflation tax, price or wage rigidities on the one hand, ${ }^{1}$ and trading frictions on asset markets on the other hand. ${ }^{2}$ Contrary to these studies on monetary policy analysis, we construct a model where monetary policy is conducted via open market operations. Since open market operations are the most commonly used instrument of monetary authorities in developed countries, we identify innovations to open market trades as exogenous monetary policy measures. ${ }^{3}$ Shocks to open market operations affect the flow of funds in the entire financial system. Thus, changes in monetary aggregates are endogenously determined by responses of the whole macroeconomic system.

The limited participation framework, which has become widely used in equilibrium monetary business cycle theory, also applies the concept of exogenous money growth. ${ }^{4}$ As its main advantage in comparison to models with goods markets frictions, the limited participation model generates rising nominal interest rates in response to decreased liquidity because households do not immediately adjust their nominal savings in response to a monetary policy shock. A financial intermediary receives deposits from the households and nominal injections from the central bank which both are supplied to the loan market. A decline in loanable funds due to monetary tightening leads to a rise in interest rates, decreasing factor inputs, which are financed by loans, and a real contraction. As Lucas (1990), Christiano (1991), and Fuerst (1992) show, the rise in interest rates due to this liquidity effect lasts only one period even if injections are persistent. Changes in monetary transfers are compensated by households' portfolio adjustments in the subsequent period. Without imposing further portfolio frictions, ${ }^{5}$ the so-called anticipated inflation effect dominates after one period, leading to declining interest rates.

\footnotetext{
${ }^{1}$ Examples of this literature include models with i) an inflation tax, e.g. Cooley and Hansen (1989), ii) cash-in advance constraints, e.g. Lucas and Stokey (1987) or Cooley and Hansen (1997), iii) sticky prices, e.g. Ohanian and Stockman (1994), Chari et al. (1996), Rotemberg (1996), Yun (1996), iv) price adjustment costs, e.g. Hairault and Portier (1994), v) wage rigidities, e.g. Cho and Cooley (1995) or Jeanne (1998), to name but a few.

${ }^{2}$ In models of limited participation, e.g. Lucas (1990), Fuerst (1992), Cristiano and Eichenbaum (1992), Christiano and Eichenbaum (1995), and Christiano et al. (1997a), real effects of monetary injections are due to an unsyncronized participation of households and firms in financial markets.

${ }^{3}$ An alternative choice of the monetary policy instrument has been prominently applied in recent work on business cycle modeling. Following Taylor (1993), the monetary authority is assumed to set the shortterm nominal interest rate depending on the history of inflation, output, and the interest rate itself. See, for example, Rotemberg and Woodford $(1997,1998)$ and McGrattan (1999). Especially in the case of an interestrate rule, the rational expectations equilibrium is often indeterminate (see, e.g., Bernanke and Woodford, 1997, and Christiano et al., 1997b).

${ }^{4}$ As an exception, Chari et al. (1995) also introduce an 'endogenous' component to money creation as they tie the money growth rate to the rate of technological innovation in their model. They assume banks to hold both borrowed and non-borrowed reserves in order to produce demand deposits and are able to study the cyclical behavior of various monetary aggregates.

${ }^{5}$ In order to generate persistent liquidity effects, Chari et al. (1995) and Cooley and Quadrini (1999) assume that the adjustment of households' portfolios is costly.
} 
We start our analysis with the assumption that the monetary authority is able to control the ratio of open market securities outstanding to non-borrowed reserves of banks. By applying vector autoregressive representations of the macroeconomic system, we provide empirical evidence that orthogonal shocks to such a ratio reasonably measure exogenous disturbances to monetary policy. Responses of real GDP, prices, money growth, and interest rates to open market shocks are comparable to the responses of these variables to federal funds rate innovations, whereas responses to alternative measures are clearly less pronounced. These results as well as the responses of various other macroeconomic variables support our identification of monetary policy shocks in our business cycle model with innovations to the ratio of the assets exchanged in open market operations, namely, securities and reserves.

When the monetary authority tightens monetary policy, it uses swaps of ownerships over securities. It provides reserves in exchange for open market instruments, typically in the form of government debt. As the monetary authority controls the open market ratio, it affects the liquidity of the entire financial system and the portfolio composition of banks and households in our model. ${ }^{6}$ Banks react to a contractionary monetary policy measure by adjusting their security holdings, their reserves, and their lending to firms. Accordingly, total reserves of the banking system are determined by both monetary policy measures and money demand by the banks. Interest rates are mainly determined by changes in the liquidity of the financial system, leading to a persistent rise in nominal interest rates in response to a monetary tightening. With higher lending rates, the prices of labor and capital rise as the factor remunerations has to be financed by loans and, consequently, factor demand and production decline.

We develop a quantitative general equilibrium model of the US economy. We abstract from trading frictions. Money is introduced in the utility function. We also aim to add to the recent literature, e.g. Ohanian et al. (1995), Chari et al. (1996), or Yun (1996), which has discussed the effects of sticky prices on the propagation mechanism, and allow for price staggering in our model. As another distinguishing feature of our model, we incorporate a banking sector with costly financial intermediation. ${ }^{7}$ Banks take funds from households and lend these funds to firms with lending rates exceeding the rate of return on open market instruments, namely, bonds. In order to abstract from liquidity effects due to limited participation, households funds are deposited at banks and withdrawn within one period. Monetary policy works in part via bank lending and in part via price stickiness.

The specification of monetary policy in the form of open market operations is contrasted with the standard approach to describe monetary policy by exogenous money growth. The performance of the business cycle models with these two specifications for monetary policy is assessed by comparing the models implications for the behavior of macroeconomic variables with empirical observations from the postwar US economy. In particular, we estimate VARs and compare the empirical responses to monetary policy shocks with the ones implied by our models. Furthermore, we compare the empirical correlations of various variables with the corresponding correlations as computed from the simulations of our theoretical models.

\footnotetext{
${ }^{6}$ Schreft and Smith (1998) apply a similar specification of monetary policy to investigate long-run effects of monetary policy regimes. They show that, in an OLG model, changes in the monetary policy stance can generate multiple equilibria with ambiguous effects on real activity.

${ }^{7}$ Díaz-Giménez et al. (1992) provide a general equilibrium model with a similar banking sector. Contrary to our model, Díaz-Giménez et al. assume banks to intermediate between households and the government sector and, in particular, the interest rate on government bonds to be exogenous.
} 
In accordance with recent literature on monetary business cycles, we find that a business cycle model with exogenous monetary growth has various deficiencies in reproducing the empirical effects of monetary policy shocks. ${ }^{8}$ Endogenizing money in our benchmark model where monetary policy is conducted by open market operations helps to overcome most of these deficiencies. In particular, nominal interest rates rise persistently in response to tight money. Compared to the monetary injection case, the impulse response function of output displays persistence especially if prices are more flexible. Furthermore, contemporaneous correlations of the monetary policy measures and output, different monetary aggregates, nominal assets, inflation, interest rates, and velocity implied by the simulation of our theoretical model accord well with empirical observations. The performance of our model with respect to the magnitudes of the responses to monetary policy shocks is strongly improved when price stickiness is introduced into the model.

The organization of the paper is as follows. Section 2 provides short-run empirical effects of different monetary policy measures. We present our results from empirical estimates based on VAR analysis of US data over the period 1960:1 - 1999:1. In section 3, our model is introduced and calibrated with regard to characteristics of the US economy. In section 4, the numerical results of the model are presented. First, we present impulse responses for the two money shocks considered in this paper, the open market operations shock and the money growth shock. Second, we study the effect of different model specifications on the persistence and the amplitude of the impulse response function of output. Finally, we present second moment properties for our theoretical models and compare them with the empirical counterparts. Section 5 concludes.

\section{Empirical Effects of Monetary Policy Shocks}

In this section we present empirical evidence on the effects of monetary policy shocks. In business cycle models innovations to broad monetary aggregates are commonly used as a measure of monetary policy. A change in such an aggregate, however, does not only depend on exogenous policy disturbances, but also on money demand. Obviously, in empirical analyses of monetary policy effects, other measures needs to be applied which appropriately reflects exogenous changes of monetary policy. As proposed by Bernanke and Blinder (1992) and Sims (1986), we choose the federal funds rate as the monetary policy instrument in our benchmark analysis. Our second measure of the monetary policy instrument employs the assets which are exchanged between the monetary authority and the banks in the course of open market operations. In particular, we choose the ratio of outstanding open market papers to non-borrowed reserves of banks. This measure, of course, reflects the view that the monetary authority conducts monetary policy only via open market operations.

In order to identify the shocks to monetary policy, we assume that the Federal Reserve follows a specific policy rule for its choice of the interest rate or, respectively, the open market ratio. As in Christiano et al. (1996) and Sims and Zha (1998), the monetary policy rule depends on the current and past state $\Gamma_{t}$ of the economy. Monetary policy shocks can be identified by serially uncorrelated innovations $\epsilon_{t}^{i n s t r}$ in the linear monetary policy rule: $I N S T R_{t}=g\left(\Gamma_{t}\right)+\epsilon_{t}^{i n s t r}$, where INSTR denotes the prevailing policy instrument and $g$ is a linear function. This specifications allows us to measure the impulse responses of a variable to a monetary policy shock by a regression of this respective variable on the history of the

\footnotetext{
${ }^{8}$ See Christiano and Eichenbaum (1997) and Cooley and Hansen (1998).
} 
Figure 1: Impulse Responses to One S.D. INSTR Innovations \pm 2 S.E.

\section{A. INSTR $=$ FFRATE}
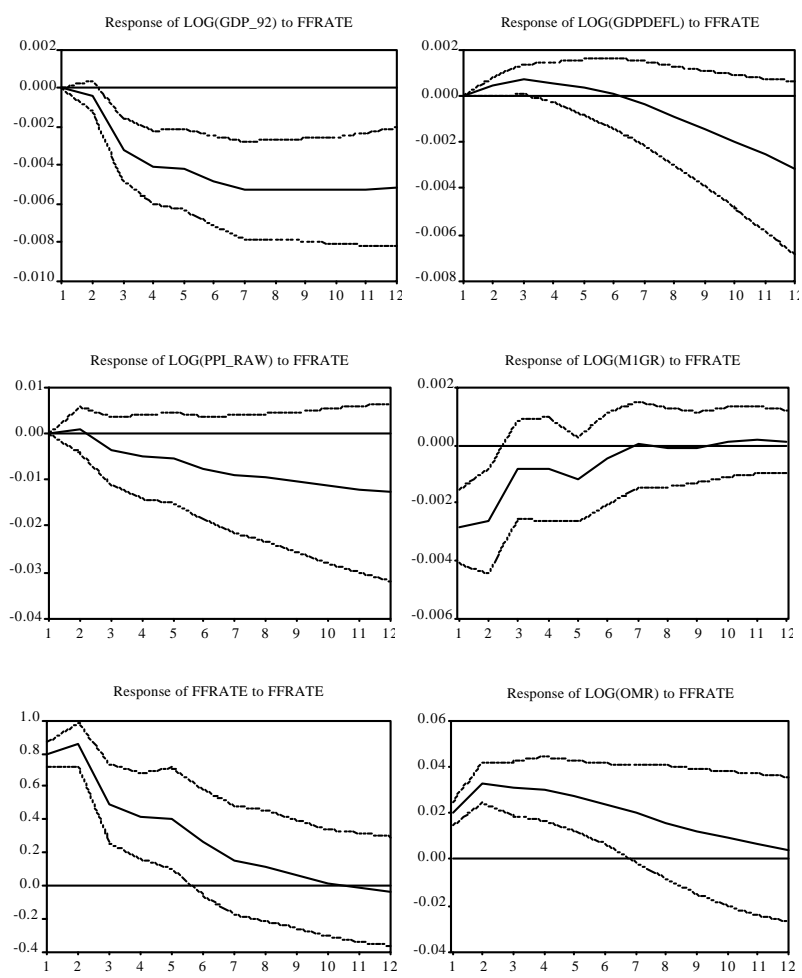

Response of LOG(OMR) to FFRATE

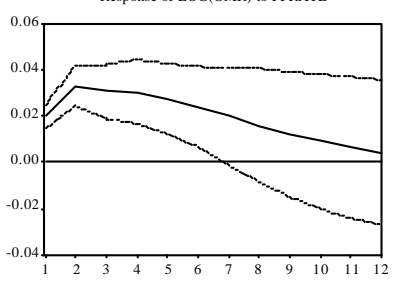

B. $\mathrm{INSTR}=\mathrm{OMR}$
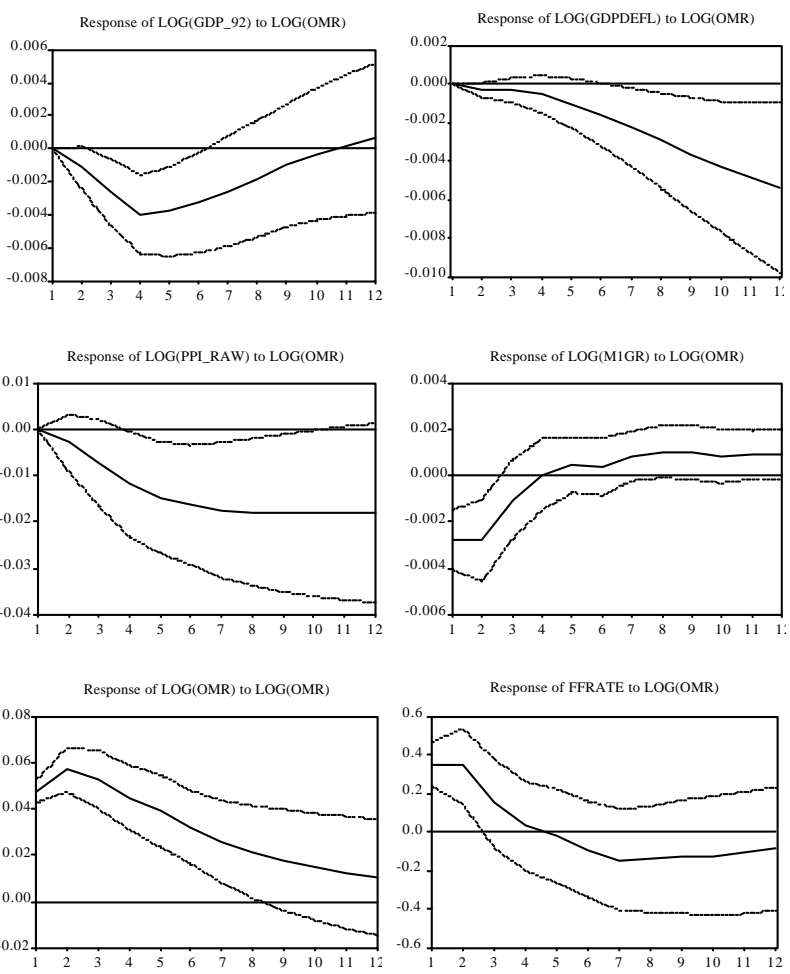

Note: The impulse response functions are computed from the 5-variable VARs: (GDP_ 92, GDPDEFL, $P P I \_R A W, I N S T R, M 1 G R$ ), with INSTR $\in\{F F R A T E, O M R\}$. For the computation of the last impulse response in each set $M 1 G R$ is replaced by $D \in\{F F R A T E, O M R\}$ in the 5-variable VAR.

residuals $\epsilon^{\text {instr }}$. We compute the impulse responses of various variables to policy innovations from fitting a particular vector autoregression (VAR). The estimation errors are orthogonalized by a Choleski decomposition so that the covariance matrix of the resulting innovations $\epsilon_{t}$ is diagonal. Policy innovations $\epsilon_{t}^{\text {instr }}$ are obtained using the following ordering of the variables: $\left(\Theta_{t}, I N S T R_{t}, D_{t}\right)$, where $\Theta_{t}$ denotes the $j$ contemporaneous variables in $\Gamma_{t}$ and $\epsilon_{t}^{i n s t r}$ is the $(j+1)$ th element of $\epsilon_{t}$. The recursive ordering implies that the vector $\Theta$ has a contemporaneous impact on the policy measure, whereas $D$ affects the measure INSTR only via lagged values.

The VARs are estimated with quarterly data over the period 1960:1-1999:1, using four lags of the variables. All variables are seasonally adjusted and, with the exception of rates, logged. Considering the small data sample, we keep the amount of variables in the VAR as small as possible. The vector $\Theta$ contains GDP in prices of 1992 (GDP_92), the GDP deflator $(G D P D E F L)$, and the PPI of raw materials as an index of sensitive prices (PPI_RAW). ${ }^{9}$ The aim to include a contemporaneous sensitive price index in the information set is to get rid of the so-called "price puzzle" in VARs when monetary policy shocks are identified with innovations in the federal funds rate or in non-borrowed reserves. ${ }^{10}$ Hence, each VAR

\footnotetext{
${ }^{9}$ This type of information assumption is also applied by Bernanke and Blinder (1992), Strongin (1995), and Christiano et al. $(1996,1999)$, among others. Our specification departs from these studies with respect to the choice of a sensitive price index. E.g., Christiano et al. (1999) apply a component in the Bureau of Economic Analysis' index of leading indicators as a sensitive commodity price index.

${ }^{10}$ Sims (1992) provides a discussion of this solution of the counter-intuitive price behavior in monetary VARs.
} 
contains five macroeconomic variables. The following figures present impulse responses of various economic variables $(\Theta$ and $D)$ to one standard deviation of the prevailing monetary policy innovation. The standard errors used for the impulse response functions are computed by applying the Monte Carlo method with 100 repetitions. Point estimates are represented by solid lines and the two standard error band, providing a 95\% confidence interval, is given by the dashed lines. The time axis displays quarterly periods.

In Fig. 1 the impulse response functions of selected variables are displayed for a shock to the two monetary policy instruments under consideration, the federal funds rate (FF RATE) and the open market ratio $(O M R)$. In our benchmark specification, the money growth rate of M1 $(M 1 G R)$ is chosen as the variable $D$ and, therefore, affects monetary policy only with a lag. ${ }^{11}$ In additional VARs we replace $M 1 G R$ by the other monetary policy measure $(D=O M R$ or FFRATE). Fig. 1A presents responses of economic variables to an innovation in the federal funds rate $(F F R A T E)$. In accordance with related studies, e.g. Christiano et al. (1999), we find that the rise of the FFRATE in response to its innovations is persistent. Production declines with a short delay, while money growth decreases and $O M R$ falls immediately. The price index of raw materials declines after two periods, but not significantly. The counter-intuitive rise in the GDP deflator is reduced by the introduction of $P P I-R A W$, even though it is not completely offset during the first periods.

Our second policy measure is the relation between the assets exchanged in open market operations, namely securities and high-powered money. We identify the first one with the total amount of open market papers outstanding $(O M P A P)$. For the second type of asset we apply non-borrowed reserves $(N B R E S)$. The resulting monetary policy measure, which is computed as: $O M R=\frac{O M P A P}{N B R E S}$, can also be interpreted as the inverse of the relative price of non-borrowed reserves in terms of open market securities. We suggest that this measure is more suitable than pure monetary aggregates, such as M1, M0, or reserves, for the identification of exogenous monetary policy disturbances. ${ }^{12}$ Fig. $1 \mathrm{~B}$ presents the dynamic responses of macroeconomic variables which are computed with a VAR using the innovations to the open market ratio $(O M R)$ as the measure of monetary policy shocks. The pattern of these responses is almost identical to those presented in Fig. 1A. The decline in output is significant until the 6th period, but it is less pronounced and persistent compared to the output response to FFRATE innovations. The responses of $M 1 G R, O M R$, and FFRATE are very similar compared to the latter case, although, they differ in the amplitude. Most noteworthy and in contrast to the case of the FFRATE shocks the responses of prices display no tendency to rise and even decline significantly after 4-6 periods.

We also apply other measures of monetary policy shocks, namely, changes in total open market papers, non-borrowed reserves, non-borrowed reserves adjusted for contemporaneous changes in total reserves $(N B R X),{ }^{13}$ and changes in the growth rate of M1. Except for $O M P A P$, these monetary policy measures are also applied by Christiano et al. (1999) in

\footnotetext{
${ }^{11}$ All growth rates in this paper are computed as the ratio of two successive values (e.g.: $M 1 G R=$ $\left.M 1_{t} / M 1_{t-1}\right)$.

${ }^{12}$ See Eichenbaum (1991) and Christiano and Eichenbaum (1995) for a discussion of the appropriateness to identify changes in non-borrowed reserves rather than changes in broader monetary aggregates like M0 or M1 as a measure for monetary policy shocks. Strongin (1995) even argues that changes in reserves are mainly driven by the Federal Reserves accomodation of changes in the demand for reserves.

${ }^{13}$ This measure of exogenous monetary policy shocks has been proposed by Strongin (1995) in order to control for changes in the demand for reserves. We follow Christiano et al. (1999) and implement this measure by setting INSTR $=N B R E S$ and including total reserves $\left(\right.$ TOTRES) in $\Theta_{t}$.
} 
their VAR analyses of various monetary policy shock measures. We find that the impact of the innovations in these measures on output, prices, the growth rate of M1, and the federal funds rate is less pronounced than the impact of $O M R$ innovations or even insignificant. ${ }^{14}$ The impulse responses of the respective VARs, similar to those underlying Fig. 1, are displayed in Fig. A1 in Appendix A.

The effects of both monetary policy shocks (FFRATE,OMR) on further variables are presented in Fig. 2. Here, we focused on the already mentioned financial variables $(O M P A P, N B R E S)$ and credit market instruments at the Federal Reserve (DEBT_FR), the 3 month T-bill rate $\left(T B I L L_{-} R\right)$, the bank prime loan rate $\left(P R L O A N_{-} R\right)$, bank loans $(B L O A N S)$, the growth rate of the monetary base $(M 0 G R)$ and of M2 $(M 2 G R)$, as well as the non-financial variables employment $(E M P L)$, the standardized unemployment rate (UNEMPL_R), corporate profits (PROFITS), and the growth rate of the consumer price index $C P I_{t} / C P I_{t-1}(I N F L)$.

In response to a federal funds rate shock, debt holdings of the Federal Reserve and nonborrowed reserves decline immediately (see Fig. 2A). The amount of open market papers rises strongly. The increase in both interest rates, the three-month T-bill rate and the bank prime loan rate, is even more pronounced. Employment rises initially, while it declines after 3 periods. The qualitative response pattern of the unemployment rate is opposite to the one of employment, even though the dynamic responses are statistically less significant. ${ }^{15}$ Bank loans and corporate profits decline with a delay of 2-3 periods. M2 growth displays a response similar to the response of M1 growth as presented in Fig. A1. The response of the monetary base growth rate is very small and insignificant. In accordance with the above mentioned counter-intuitive behavior of the GDP deflator, the growth rate of CPI (INFL) rises significantly in the first periods.

The responses of the macroeconomic variables to a shock in the open market ratio are graphed in Fig. 2B. Except for the response of inflation, they exhibit approximately the same pattern as the responses in Fig. $2 \mathrm{~A}$ and differ only with regard to the amplitudes. While the responses are weaker for the interest rates TBILL_R and PRLOAN_R or insignificant for $D E B T_{-} F R, B L O A N S$, and $U N E M P L_{-} R$, they are more pronounced for $P R O F I T S, N B R E S$, and $O M P A P$. Regarding the response of the inflation rate, we find an insignificant decline following a positive $O M R$ shock.

To summarize, the findings in this section confirm that the innovations to the open market ratio represent a useful alternative to the federal funds rate for the identification of monetary policy shocks. Per construction, it considers the relative change of assets at both sides of an open market transaction and identifies the flow of funds pendant to the interest rate measure (FFRATE). Further, the comparison with other monetary policy measures, such as monetary aggregates, shows that the $O M R$ measure is capable of generating more pronounced and significant responses of variables like output, money growth, interest rates, and prices, which are the common focus in the analysis of monetary policy shocks.

\footnotetext{
${ }^{14}$ Particularly, innovations of open market papers generate weaker responses of M1 growth and the federal funds rate, whereas changes in nonborrowed reserves and M1 growth have an insignificant impact on output and prices. While changes in the adjusted non-borrowed reserves measure (NBRX) are able to produce a significant ouput decline, their impact on prices and M1 growth are insignificant.

${ }^{15}$ This pattern changes when the labor market variables are included in $\Theta$. In this case, employment decreases and the unemployment rate rises moderately.
} 
Figure 2: Impulse Responses to One S.D. INSTR Innovations \pm S.E.

\section{A. INSTR $=$ FFRATE}
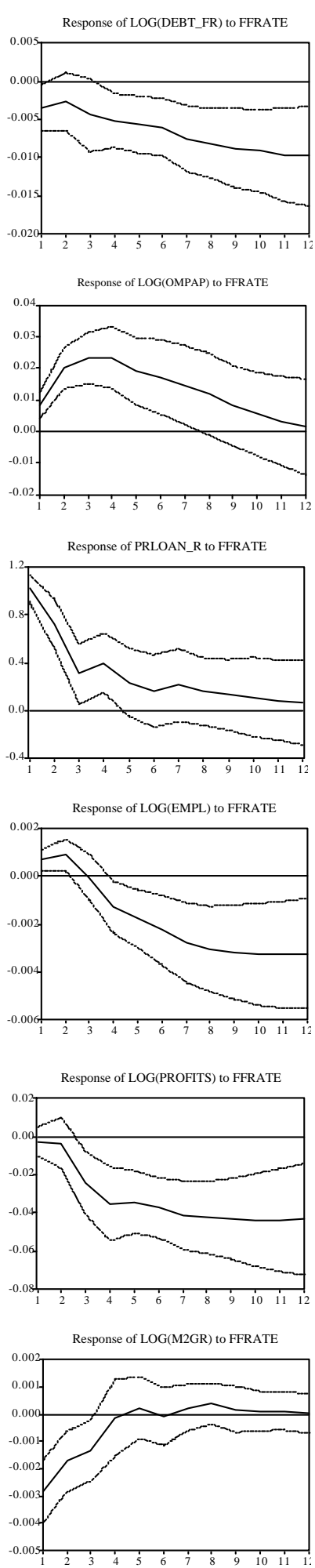

Response of LOG(NBRES) to FFRATE
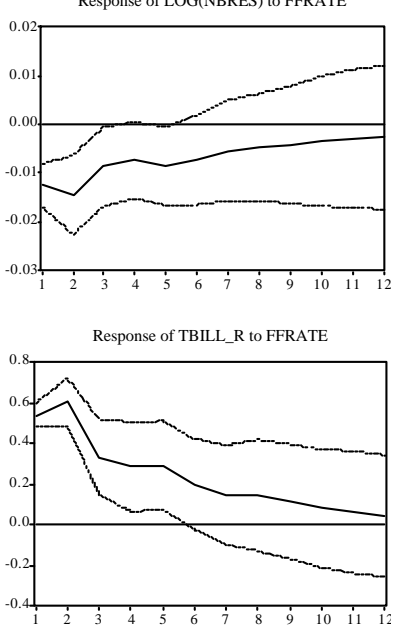

Response of LOG(BLOANS) to FFRATE

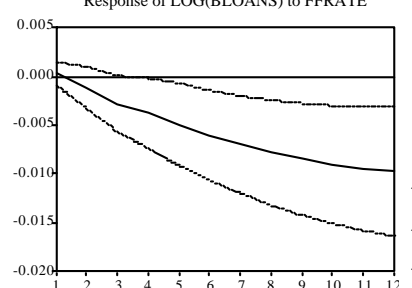

Response of UNEMPL_R to FFRATE

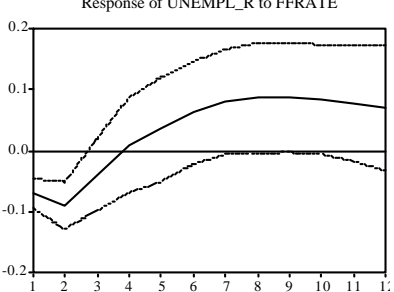

Response of LOG(M0GR) to FFRAT

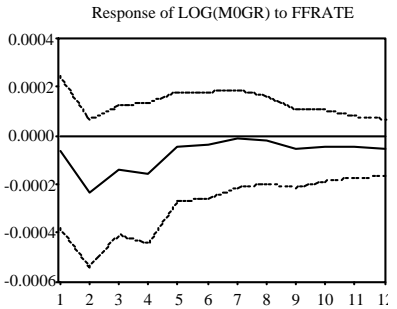

Response of LOG(INFL) to FFRATE

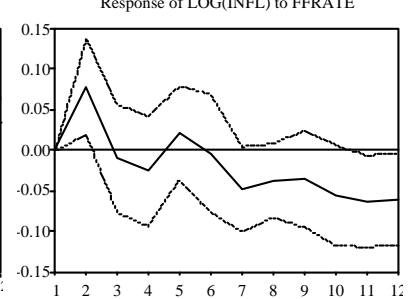

B. $\mathrm{INSTR}=\mathrm{OMR}$
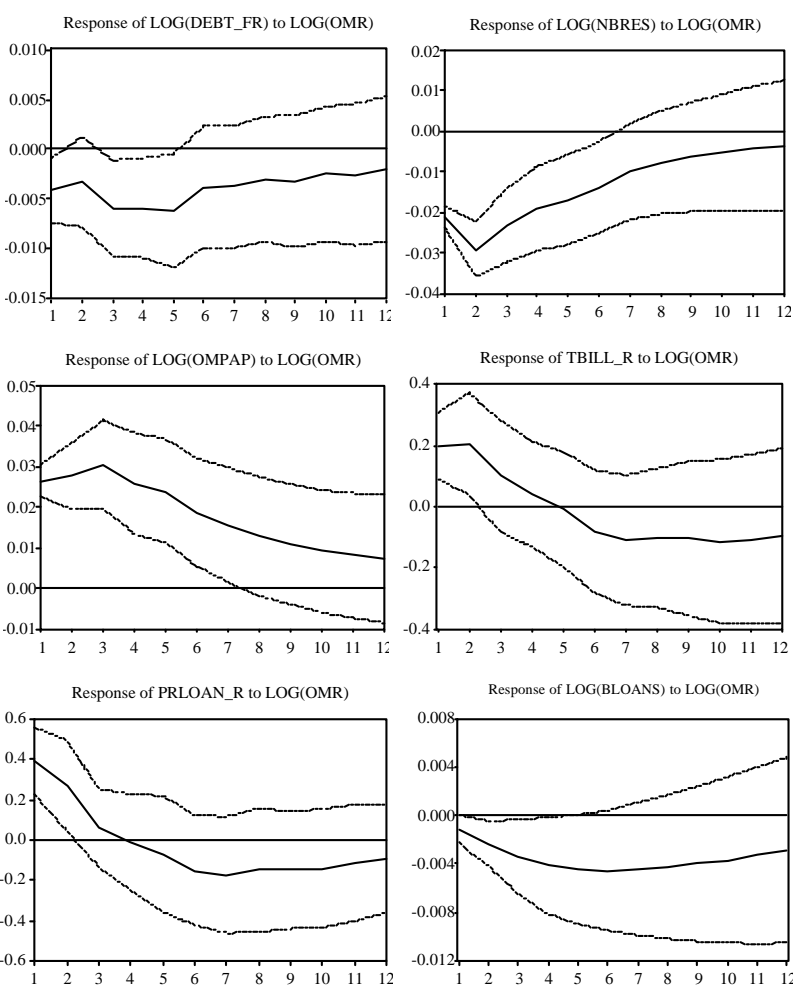

Response of LOG(BLOANS) to LOG(OMR)
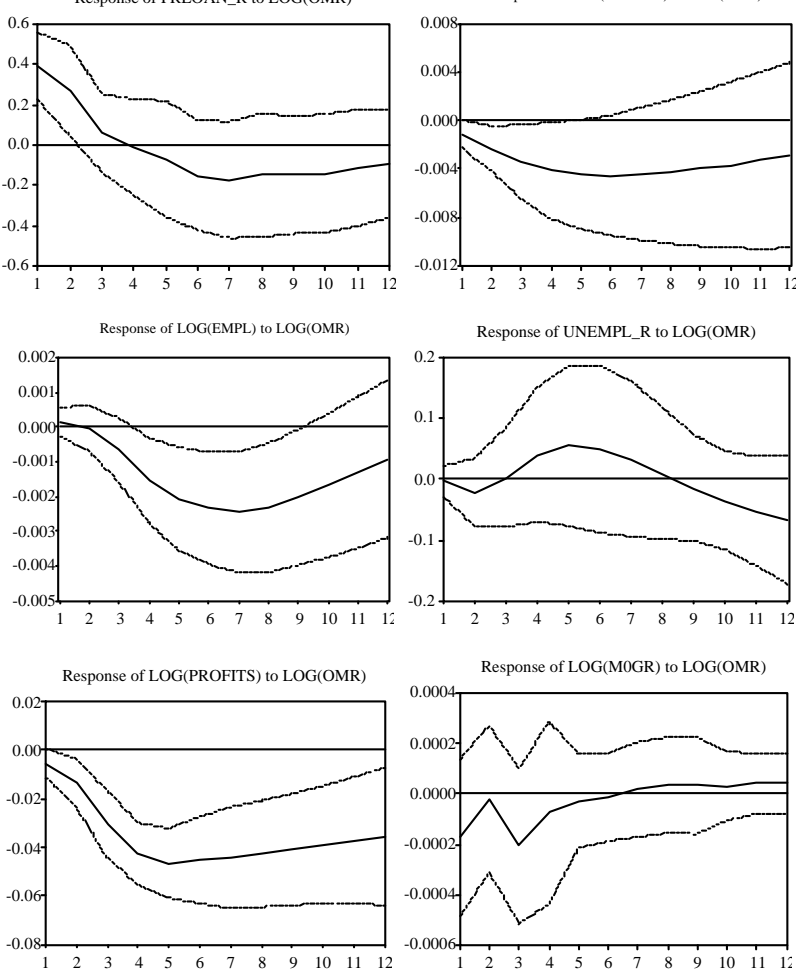

Response of LOG(M2GR) to LOG(OMR)

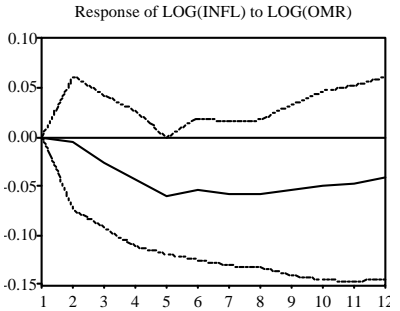

Note: The respective VARs are estimated with five variables: (GDP_92, GDPDEFL, PPI_RAW, INSTR, $D$ ), where INSTR $\in(F F R A T E, O M R)$ is the monetary policy measure and $D$ is the variable whose responses are displayed in the figure. 


\section{The Model}

In this section we present a dynamic general equilibrium model with a financial intermediary sector. It distinguishes between two monetary aggregates, inside money and outside money. This feature, in particular, allows us to study the propagation of monetary shocks via the banking sector. Lending is assumed to be costly. We employ open market operations as exogenous monetary policy measures in our benchmark case. For comparison, we also consider a monetary policy characterized by exogenous money growth. Price stickiness is introduced via monopolistic retailers who set their prices according to Calvo's (1983) staggered price setting. Further, we consider adjustment costs in the accumulation of physical capital.

\subsection{Households}

We assume that households are identical and of measure one. The expected lifetime utility of a representative household over an infinite horizon is given by:

$$
E_{0}\left[\sum_{t=0}^{\infty} \beta^{t} u\left(c_{t}, \frac{M_{t}}{p_{t}}, 1-l_{t}\right)\right], \text { with } 0<\beta<1 .
$$

Expectations $E_{t}$ are taken conditional on informations at the beginning of period $t$. The instantaneous utility $u$ (.) is discounted with the factor $\beta$. The utility function $u$ is logarithmic in consumption $c$, real money balances $m=\frac{M}{p}$ and leisure $1-l$ :

$$
u\left(c_{t}, \frac{M_{t}}{p_{t}}, x_{t}\right)=\gamma \ln c_{t}+(1-\gamma) \ln \frac{M_{t}}{p_{t}}+\eta \ln \left(1-l_{t}\right), \text { with } \eta, \gamma>0
$$

The time endowment is normalized to one. Hence, labor supply equals $l$. Total assets of the households comprise government bonds $B^{h}$, physical capital $k$, and cash $M$. Nominal assets $\left(B^{h}, M\right)$ are denoted by upper-case letters, while real assets $\left(b^{h}, k, m\right)$ are denoted by lower-case letters. Households are the owners of the firms, banks, and retailers. The budget constraint of the representative household can be written as:

$$
p_{t} c_{t}+M_{t+1}+B_{t+1}^{h}+p_{t} e_{t}=M_{t}+\left(1+i_{t}\right) B_{t}^{h}+p_{t} w_{t} l_{t}+p_{t} r_{t} k_{t}+p_{t} \tau_{t}+p_{t} \stackrel{f}{t}+p_{t} \quad \stackrel{b}{t}+p_{t} \quad \stackrel{r}{t},
$$

where $p, e, w, r, i, \tau, \quad{ }^{f}, \quad{ }_{t}^{b}$, and ${ }_{t}^{r}$ denote the price level, investment expenditures, the wage, the real rate of return on physical capital, the nominal rate of return on bonds, a lump-sum transfer from the government, and the dividends from firms, banks, and retailers. The households' debt holdings are managed by banks and both their wage income and their capital income are deposited into checking accounts. We introduce adjustment costs of investment expenditures in physical capital. Capital evolves according to:

$$
k_{t+1}=\Phi\left(\frac{e_{t}}{k_{t}}\right) k_{t}+(1-\delta) k_{t}
$$

where $\delta$ denotes the depreciation rate of capital and the adjustment cost function $\Phi($.$) is$ increasing and concave with $\Phi(0)=0 .{ }^{16}$ The introduction of adjustment costs provides a variable price of physical capital $q$ in terms of the numeraire good and drives a wedge between

\footnotetext{
${ }^{16}$ This function can also be interpreted as marginal adjustment costs in the production of capital. Investment expenditures $e$ yield a gross output of new capital goods $\Phi(e / k) k$.
} 
the real return on capital and the real return on bonds. The adjustment cost function is chosen to generate a steady state value of the capital price $q$ equal to one.

Maximizing lifetime utility (1) subject to the flow constraint (3) and the accumulation equation (4) with respect to consumption, leisure, investment expenditures, physical capital, bond holdings, and cash leads to the following first order conditions:

$$
\begin{aligned}
\lambda_{t} & =\gamma / c_{t}, \\
\lambda_{t} w_{t} & =\eta /\left(1-l_{t}\right), \\
q_{t} & =\frac{1}{\Phi^{\prime}(.)} \\
q_{t} & =E_{t}\left[\frac{r_{t+1}+q_{t+1}\left[\Phi\left(\frac{e_{t+1}}{k_{t+1}}\right)-\Phi^{\prime}\left(\frac{e_{t+1}}{k_{t+1}}\right) \frac{e_{t+1}}{k_{t+1}}+(1-\delta)\right]}{\left(1+i_{t+1}\right) \frac{p_{t}}{p_{t+1}}}\right], \\
\frac{1}{\beta} & =E_{t}\left[\frac{\lambda_{t+1}}{\lambda_{t}}\left(1+i_{t+1}\right) \frac{p_{t}}{p_{t+1}}\right], \\
\frac{\lambda_{t}}{\beta} & =E_{t}\left[\left(\frac{1-\gamma}{m_{t+1}}+\lambda_{t+1}\right) \frac{p_{t}}{p_{t+1}}\right] .
\end{aligned}
$$

The Lagrangian multiplier $\lambda$ is associated with the budget constraint (3). The first two equations guarantee that the households equate the marginal utilities of both goods (consumption and leisure) to the marginal utility of wealth times the price of the respective good. The shadow price of physical capital $q^{*}$, which equals the Lagrangian multiplier associated with (4), can be derived by multiplying $\lambda$ with the market price of capital $q$. Equation (7) determines the market price of capital. The last three equations are arbitrage conditions concerning the return on physical capital, bonds, and cash. Equation (9) is the standard intertemporal allocation condition. Equation (10) describes the optimal allocation of cash over time.

\subsection{Production}

Identical and perfectly competitive firms produce the wholesale good $y$. We assume that production technology is Cobb-Douglas employing two production factors, i.e. capital $k$ and labor $l$ :

$$
y_{t}=a_{t} k_{t}^{\alpha} l_{t}^{1-\alpha}, \text { with } 0<\alpha<1,
$$

where $a$ denotes the stochastic total factor productivity level generated by an AR1 process:

$$
\log a_{t}=\rho^{a} \log a_{t-1}+\varepsilon_{t}^{a} .
$$

The autoregressive parameter $\rho^{a}$ is less than one and the innovations $\varepsilon^{a}$ are i.i.d., with $\varepsilon^{a} \sim N\left(0, \sigma_{a}^{2}\right)$. Firms' profits are distributed among the firm owners, the households. Labor and capital is rented at perfectly competitive factor markets. It is assumed that firms have to use bank credits $Z_{t}$ to pay the wage bill $p_{t} w_{t} l_{t}$ and the return on physical capital $p_{t} r_{t} k_{t}$ :

$$
Z_{t}=p_{t} w_{t} l_{t}+p_{t} r_{t} k_{t}
$$

Equation (13) can also be interpreted as a credit-in-advance constraint. The funds $Z$ a firm borrows from a bank are made available in form of checking accounts. At the end of the 
period, the firm repays the loan plus interest $i^{l},\left(1+i^{l}\right) Z .{ }^{17}$ The firm's profit in period $t$ is given by:

$$
{ }_{t}^{f}=\frac{p_{t}^{w}}{p_{t}} y_{t}-\left(1+i_{t}^{l}\right) w_{t} l_{t}-\left(1+i_{t}^{l}\right) r_{t} k_{t}
$$

where $p^{w}$ is the price of the wholesale good and $x=\frac{p}{p^{w}}$ is the markup on the final good. Firms maximize their profits subject to the labor and capital input. The first order conditions of a representative firm are given by:

$$
\begin{aligned}
w_{t} & =\frac{p_{t}^{w}}{p_{t}}(1-\alpha) a_{t} k_{t}^{\alpha} l_{t}^{-\alpha}\left(1+i_{t}^{l}\right)^{-1}, \\
r_{t} & =\frac{p_{t}^{w}}{p_{t}} \alpha a_{t} k_{t}^{\alpha-1} l_{t}^{1-\alpha}\left(1+i_{t}^{l}\right)^{-1} .
\end{aligned}
$$

The firms equate the marginal cost of a unit of labor (capital) to the marginal productivity of labor (capital).

\subsection{Retail}

A price rigidity is introduced via a retail sector. It consists of monopolistically competitive retailers. Each retailer $i \in(0,1)$ sells a quantity $y_{i}$ of the wholesale good at price $p_{i}$. The final good $y^{f}$ is given by a CES aggregate of the individual retail goods $y_{i}$ :

$$
y_{t}^{f}=\left[\int_{0}^{1} y_{i t}^{\frac{(\epsilon-1)}{\epsilon}} d i\right]^{\frac{\epsilon}{\epsilon-1}},
$$

where $\epsilon$ denotes the elasticity of substitution between retail goods and is assumed to be strictly larger than one. The respective price index is defined as:

$$
p_{t}=\left[\int_{0}^{1} p_{i t}^{(1-\epsilon)} d i\right]^{\frac{1}{1-\epsilon}} .
$$

The demand curve for each retailer is given by

$$
y_{i t}=\left(\frac{p_{i t}}{p_{t}}\right)^{-\epsilon} y_{t}^{f} .
$$

We assume that retailers set their prices according to Calvo's (1983) staggered price setting. The retailer changes its price in a given period with probability $(1-\phi)$. This behavior can be interpreted as retailers changing prices only at the time they receive a price-change signal. The probability of receiving such a signal $(s-t)$ periods from period $t$ is assumed to be independent of the last time the signal has been received, $\phi^{s-t}$. A retailer who does not receive a signal sets its price according to the following rule:

$$
p_{i t}=\bar{\pi} p_{i t-1},
$$

where $\bar{\pi}$ denotes the steady state value of the gross inflation rate $\pi_{t}=\frac{p_{t}}{p_{t-1}}$. A retailer who receives a price-signal in period $t$ chooses a price $\widetilde{p}_{i t}$ to maximize his expected discounted

\footnotetext{
${ }^{17}$ As will be shown below, the lending rate exceeds the rate of return on bonds in equilibrium, $i^{l}-i>0$.
} 
profits, given the information set in period $t$ :

$$
\max _{\widetilde{p}_{i t}} E_{t}\left[\sum_{s=0}^{\infty}(\beta \phi)^{s} \lambda_{t+s}\left(\bar{\pi}^{s} \widetilde{p}_{i t} y_{i t+s}-p_{t+s}^{w} y_{i t+s}\right)\right],
$$

where the discount factor is given by the owners of the retail firms, the households. Maximizing (20) with respect to $\widetilde{p}_{i t}$, taking the price $p^{w}$ of the wholesale good as given, yields the following first-order condition for the optimal price $\widetilde{p}_{i t}$ :

$$
\widetilde{p}_{i t}=\frac{\epsilon}{\epsilon-1} \frac{E_{t} \sum_{s=0}^{\infty}(\beta \phi)^{s} \lambda_{t+s} y_{t+s}^{f} p_{t+s}^{\epsilon} \bar{\pi}^{-\epsilon s} p_{t+s}^{w}}{E_{t} \sum_{s=0}^{\infty}(\beta \phi)^{s} \lambda_{t+s} y_{t+s}^{f} p_{t+s}^{\epsilon} \bar{\pi}^{(1-\epsilon) s}} .
$$

According to the price aggregation rule (18), the price index $p_{t}$ is given by:

$$
p_{t}=\left[\phi\left(\bar{\pi} p_{t} / \pi_{t}\right)^{1-\epsilon}+(1-\phi) \tilde{p}_{t}^{1-\epsilon}\right]^{\frac{1}{1-\epsilon}} .
$$

The price index adjusts only partially to changes in demand. With price staggering, output and the price index rise with increasing demand. ${ }^{18}$

\subsection{Financial Intermediation}

Financial intermediation is conducted by banks which transform deposits from households to loans. Banking is assumed to be costly and is affected by financial regulation and monetary policy measures. The monetary authority imposes a reserve-requirement ratio $\theta$ on total funds deposited by households. Banks hold these reserves at the monetary authority. We assume that no interest is paid on reserves. Further, the monetary authority is assumed to conduct open market operations. We apply the same specification of the monetary policy measure as in our empirical analysis in section 2 . Hence, monetary policy shocks are modelled as exogenous changes in the ratio $\mu^{o m r}$ of the total amount of bonds $B$ held by the agents in the economy to reserves $S: \mu_{t}^{o m r}=B_{t+1} / S_{t}$. Since we do not consider optimal government policies, the monetary policy measure $\mu^{o m r}$ is assumed to be stochastic.

As an alternative measure of monetary policy, we consider exogenous growth of a monetary aggregate as it is common in the literature on monetary business cycle theory. For this case, the growth rate of the monetary base $H_{t}$, which consists of cash holdings of households and banks' reserves, is assumed to be stochastic: $\mu_{t}^{m g r}=H_{t+1} / H_{t}$. Both policy measures are generated by the following first-order vector autoregressive process:

$$
\log \mu_{t}^{i}=\rho^{i} \log \mu_{t-1}^{i}+\left(1-\rho^{i}\right) \log \bar{\mu}^{i}+\varepsilon_{t}^{i}, \text { for } i=o m r, m g r .
$$

The autoregressive parameters $\rho^{i}$ are smaller than one and the innovations $\varepsilon^{i}$ are i.i.d., with $\varepsilon^{i} \sim N\left(0, \sigma_{i}^{2}\right)$ for $i=o m r, m g r$.

The banking sector is assumed to be perfectly competitive. Banks take deposits from the households and provide loans $Z$ to the firms at the rate $i^{l}$. Further, they hold bonds $B^{b}$ and reserves $S$. The households are assumed to deposit their factor remunerations $p_{t} w_{t} l_{t}+p_{t} r_{t} k_{t}$ at the beginning of the period at the bank. As the households withdraw these funds at the end of the same period, they do not receive interest on these funds. ${ }^{19}$ Banks' liabilities must

\footnotetext{
${ }^{18}$ Total dividends of the retail sector amount to ${ }_{t}^{r}=\left(1-1 / x_{t}\right) y_{t}$.

${ }^{19}$ The timing of deposit and withdrawal of funds follows Chari et al. (1995).
} 
equal their total assets:

$$
B_{t}^{h}+p_{t} w_{t} l_{t}+p_{t} r_{t} k_{t}=S_{t}+B_{t}+Z_{t}
$$

where total bonds $B$ equal $B^{h}+B^{b}$. Banks hold high-powered money, i.e. reserves, to fulfill the reserve requirements imposed on deposit holdings. Since high-powered money is a non-interest bearing asset, banks do not hold excess reserves in equilibrium:

$$
S_{t}=\theta\left(p_{t} w_{t} l_{t}+p_{t} r_{t} k_{t}\right)
$$

where $\theta$ denotes the reserve requirement ratio. We assume that lending is costly. These costs can be rationalized by screening and monitoring activities of banks. The costs $\Psi(z)$ are increasing in real loans. Banks' real profits in period $t$ are given by:

$$
{ }_{t}^{b}=i_{t} b_{t}^{b}+i_{t}^{l} z_{t}-\Psi\left(z_{t}\right)
$$

Taken as given the time path of the interest rates and the monetary policy variable $\left\{\mu_{t}\right\}$ the banks maximize their profits subject to (24) and (25) with respect to loans and bonds. The first order condition is given by ${ }^{20}$

$$
i_{t}^{l}=i_{t}+\Psi_{z}\left(z_{t}\right)
$$

where $\Psi_{z}\left(z_{t}\right)$ denotes the first derivative of the lending cost function.

\subsection{Government}

The government, or, equivalently, the monetary authority, sets the reserve-requirement ratio $\theta$ and the monetary policy instrument $\mu$. The government's flow constraint is given by:

$$
\left(1+i_{t}\right) B_{t}-B_{t+1}=H_{t+1}-H_{t}+p_{t} \Psi\left(z_{t}\right)-p_{t} \tau_{t} .
$$

In order to avoid social costs of intermediation we assume that banking costs $\Psi$ are private and have to be paid to the government. Although this does not accord perfectly to the banking cost rationale, these costs might be interpreted as agency payments for monitoring or administrative services. The increase in government debt, $B_{t+1}-B_{t}$, is equal to the interest payment on government debt, $i_{t} B_{t}$, minus the receipts from money creation, $H_{t+1}-H_{t}$, private costs of banking, $p_{t} \psi\left(z_{t}\right)$, and transfers $p_{t} \tau_{t}$.

\subsection{Competitive Equilibrium}

The concept of a competitive equilibrium is applied. The state variables for the representative household are $s^{e}=(K, H, B, \pi)$ and $s^{x}=(a, \mu)$, where $s^{e}$ and $s^{x}$ denote the vector of endogenous state variables and the vector of stochastic state variables, respectively. The competitive equilibrium then consists of a maximum value for the household's objective (1) and a set of decision rules for the household's decision variables $c_{t}\left(s_{t}^{x}, s_{t}^{e}\right), l_{t}\left(s_{t}^{x}, s_{t}^{e}\right)$, $M_{t+1}\left(s_{t}^{x}, s_{t}^{e}\right)$, and $e_{t}\left(s_{t}^{x}, s_{t}^{e}\right)$. Further, it consists of a corresponding set of aggregate per capita decision rules, the factor price functions $w_{t}\left(s_{t}^{x}, s_{t}^{e}\right), r_{t}\left(s_{t}^{x}, s_{t}^{e}\right)$, and $q_{t}\left(s_{t}^{x}, s_{t}^{e}\right)$, the credit function $Z_{t}\left(s_{t}^{x}, s_{t}^{e}\right)$, and the nominal interest rate functions $i_{t}\left(s_{t}^{x}, s_{t}^{e}\right)$ and $i_{t}^{l}\left(s_{t}^{x}, s_{t}^{e}\right)$. These optimal

\footnotetext{
${ }^{20}$ These conditions can also be derived by maximizing the discounted profits of a bank considering the following flow constraint: $B_{t+1}^{b}+S_{t+1}=\left(1+i_{t}\right) B_{t}^{b}+i_{t}^{l} Z_{t}+S_{t}-p_{t} \Psi\left(z_{t}\right)-p_{t}{ }_{t}^{b}$.
} 
decision rules and functions have to satisfy the following conditions: 1 . Households maximize their lifetime utility (1) taken prices as given, i.e. (5)-(9) hold. 2. The banks' and firms' profits are maximized, i.e. (15)-(16) and (27) hold. 3. The stochastic variables follow the processes described in (12) and (23). 4. The government's balanced budget constraint is satisfied (28). 5. Individual and aggregate variables are consistent. 6. All factor, asset, goods, and money markets clear:

$$
\begin{aligned}
& y_{t}^{f}=c_{t}+e_{t}, \\
& B_{t}=B_{t}^{h}+B_{t}^{b}, \\
& H_{t}=S_{t}+M_{t} .
\end{aligned}
$$

\subsection{Model Parametrization}

To calibrate the model we choose values for the preference and technology parameters which are fairly standard. ${ }^{21}$ The discount factor of households $\beta$ is set equal to $1.03^{-0.25}$. The production elasticity of capital $\alpha$ is set equal to 0.36 . Quarterly depreciation of physical capital $\delta$ is assigned a value of 0.0212 . As total time available for the households is normalized to 1 , steady state labor input is set equal to 0.3 . The utility parameter $\gamma$ is set equal to 0.996 , implying an average velocity $G D P / M 1$ of 6.79 . The steady state value of total factor productivity $a$ is set equal to 1 .

Table 1: Values of Preference and Technological Parameters

\begin{tabular}{lll}
\hline \hline Parameter & Descriptions & Value \\
\hline$\alpha$ & Production Elasticity of Capital & 0.36 \\
$\gamma$ & Parameter of Utility Function & 0.996 \\
$\epsilon$ & Substitution Elasticity of Retail Goods & 6 \\
$\beta$ & Discount Rate & 0.9926 \\
$\delta$ & Depreciation Rate of Physical Capital & 0.0212 \\
$\theta$ & Reserve Requirement Ratio & 0.06 \\
$\Phi^{\prime \prime} \frac{e}{k} / \Phi^{\prime}$ & Elasticity of Capital Adjustment Cost & -0.25 \\
$\Psi_{z}$ & Lending Spread & 0.006 \\
$\bar{l}$ & Steady State Labor Supply & 0.3 \\
$\bar{Y} / \bar{M}$ & Velocity & 6.79 \\
$\bar{B} / \bar{Y}$ & Ratio of Open Market Papers to GDP & 0.094 \\
$\phi$ & Probability of Price Adjustment & 0.75 \\
$\bar{\pi}$ & Steady State Inflation & 1.0189 \\
\hline \hline
\end{tabular}

Following Bernanke et al. (1998), the elasticity of the price of capital with respect to the investment ratio, $\Phi^{\prime \prime} \cdot\left(\frac{e}{k}\right) / \Phi^{\prime}$, is set to -0.25 . The marginal cost of loans $\Psi_{z}$ equals the average historical spread between the prime bank loan rate and the treasury bill rate (0.006). As in Chari et al. (1995), we set the reserve requirement ratio $\theta$ equal to 0.06 . The elasticity of the retail good production $\epsilon$ is assigned a value of 6 , implying a mark-up $x$ equal to $1.2 .^{22}$ The probability for a retailer to receive a price signal $1-\phi$ is set equal to 0.25 for the benchmark case. This value leads to an average price fixity duration of 3 periods (3/4

\footnotetext{
${ }^{21}$ See, e.g., Christiano and Eichenbaum (1992).

${ }^{22}$ See e.g. Christiano et al. (1997a).
} 
years). Alternatively, we will also use a value of 1, implying flexible price adjustments of the retailers. The former value seems to be justified by the empirical price responses estimated in section 2 and is also used in related analyses of monetary policy effects in sticky price models. ${ }^{23}$

Table 2: Parameter of the Stochastic Processes

\begin{tabular}{ccccccc}
\hline \hline $\bar{\mu}^{m g}$ & $\rho^{\text {omr }}$ & $\sigma^{\text {omr }}$ & $\rho^{m g r}$ & $\sigma^{m g r}$ & $\rho^{a}$ & $\sigma^{a}$ \\
1.0189 & 0.923 & 0.058 & 0.469 & 0.0129 & 0.95 & 0.0035 \\
\hline \hline
\end{tabular}

The parameters of the stochastic processes for both monetary policy measures are estimated for the period 1984:4-1994:4. ${ }^{24}$ For the open market ratio $(O M R)$, we applied the ratio of the time series of open market papers outstanding $(O M P A P)$ and non-borrowed reserves $(N B R E S)$. For the growth rate of high-powered money, we employed the growth rate of M1 $(M 1 G R)$. We also applied the time series of the growth rate of the monetary base (M0) which is more consistent with the model specification, but does not display any significant response to exogenous monetary policy shocks (Fig. 2 and 3). Our parameter estimates for M0 are very low ( $\rho=0.05, \sigma=0.0021$ for 1984:4-1994:4) compared with the parameters in similar studies which are using the time series of M1 or M2. The autoregressive parameter in (23) for the open market ratio (money growth) is estimated at 0.923 (0.469). The standard deviation of the respective residuals equals 0.058 (0.0129). The steady state inflation rate $\bar{\pi}$ which equals the steady state money growth rate $\bar{\mu}^{m g r}$ is estimated at 1.0189. The parameter $\rho^{a}$ of the AR1 process for the technological level is assigned a value which is standard in the business cycle literature $\left(\rho^{a}=0.95\right)$. The standard deviation is set so that the simulation of our benchmark model approximately replicates the empirical standard deviation of output $\left(\sigma^{a}=0.0035\right)$.

\section{The Model's Behavior and Numerical Results}

In this section, we present the qualitative properties of our model and the numerical results. In subsection 4.1, we describe the impact of the monetary policy shock on various macroeconomic variables for our benchmark case where the monetary authority conducts monetary policy via open market operations. Subsequently, we consider monetary policy in the form of a change in the exogenous money growth rate. We also perform a sensitivity analysis of our results with regard to the degree of price flexibility and study the persistence of the output responses. In subsection 4.2, we assess the moments implied by the two different specifications of our monetary policy shock and compare them to the empirical values.

\subsection{Impulse Responses to Monetary Policy Measures}

Fig. 3 presents the responses of several variables to a contractionary shock of size 0.01 in the open market ratio $(O M R)$ for the model with flexible prices $(\phi=0)$. The responses are expressed as percentage deviation from the steady state values of the respective variables. In the course of an open market operation, the monetary authority imposes a higher relation of outstanding bonds to reserves and reduces the liquidity of the financial system.

In period 1, when the shock hits the economy, we observe a decline in the inflation rate (Fig. 3D), whereas the predetermined variables bonds, high-powered money, and physical

\footnotetext{
${ }^{23}$ See e.g. King and Wolman (1996) and Jeanne (1998).

${ }^{24}$ This period can be characterized by a stable monetary policy regime (see e.g. Cooley and Hansen, 1998).
} 
A. Output y

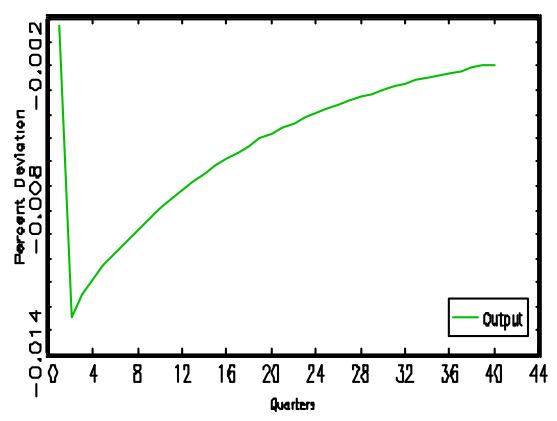

D. Inflation pi

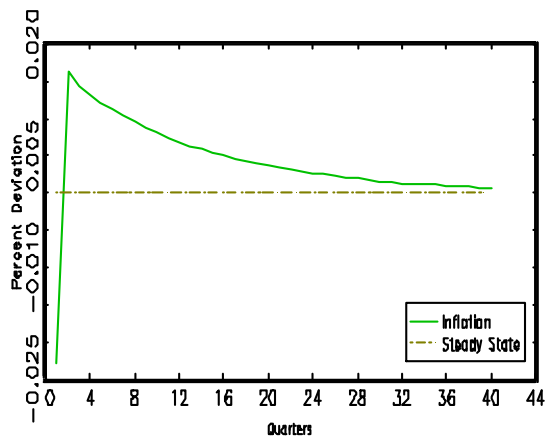

G. Real Bolance $m$ and High Powered Money $h$

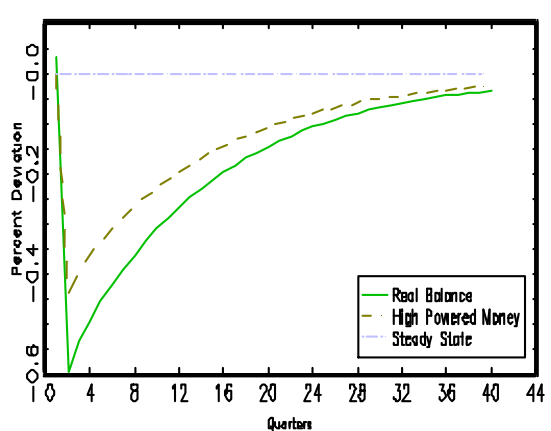

J. Employment I and Investment $\mathrm{e}$

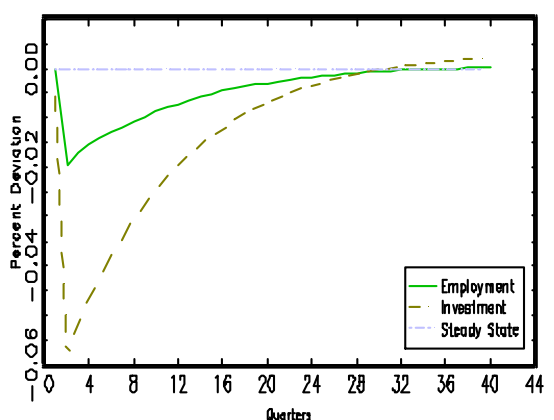

B. Total Bonds $b$ and $H H$ Bonds bh

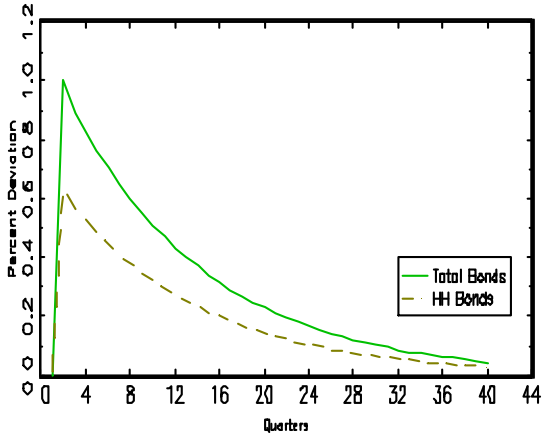

E. Return on Bonds i and Lending Rate il

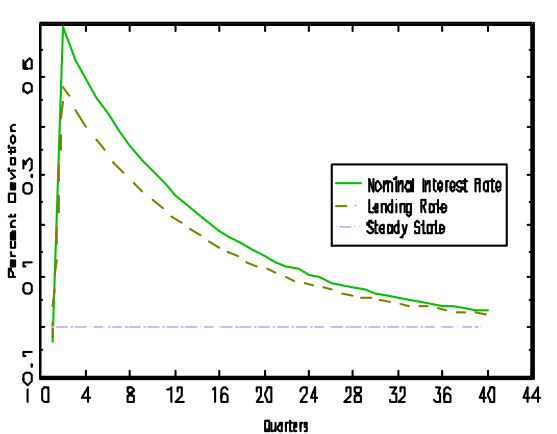

H. Copital Stock $k$ and Consumption $c$

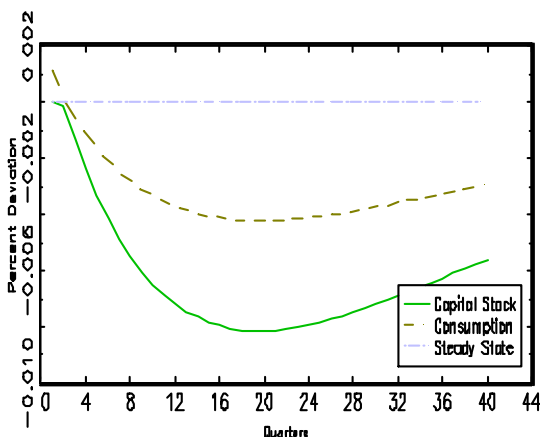

K. Retail Profits omega_r

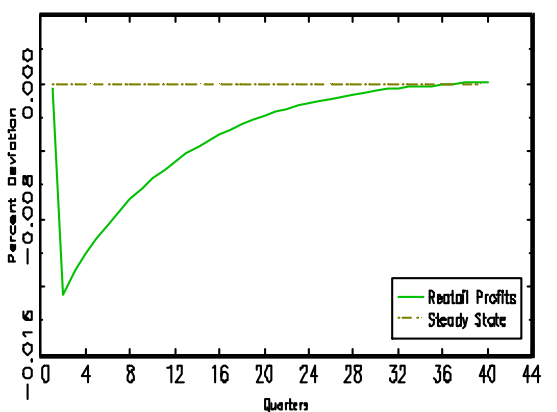

C. Reserves $\mathrm{s}$

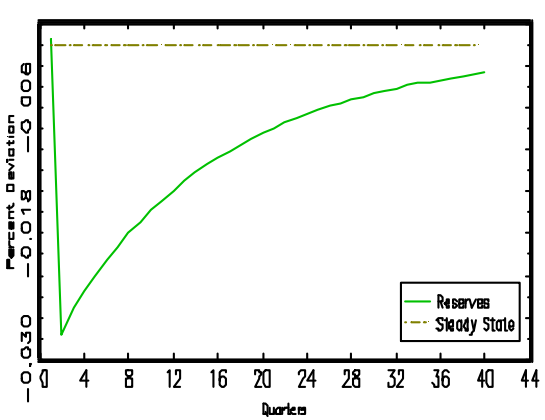

F. Wage w and Return on Capital $r$

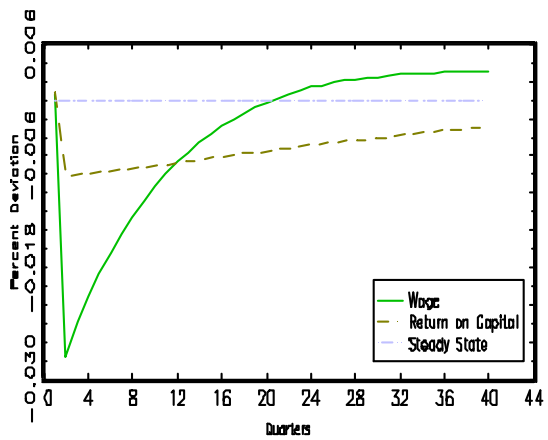

I. Loans Z

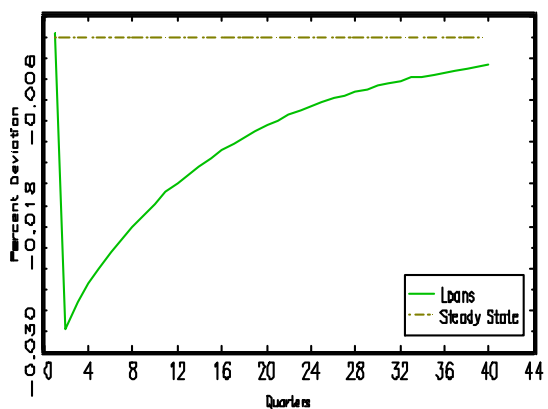

L. Real Return on Bonds ib

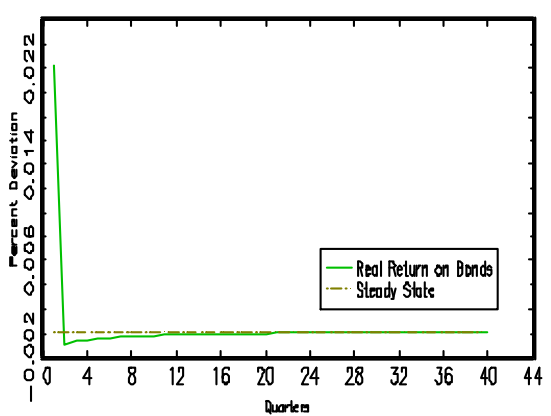

Figure 3: Response to a $1 \%$ OMR Innovation with $\phi=0$ (Deviations in \%) 
capital remain unchanged. The magnitude of the initial response of inflation to a shock depends on the degree of price stickiness (compare Fig. 4) and will be found to be one of the main factors driving our results in this section. In the subsequent periods, the macroeconomic effects, particularly the anticipated inflation effect on interest rates, are clearly dominated by the portfolio adjustment effects as resulting from the $O M R$ shock, leading to a reduction in the capital stock $k$, reserves $s$, and cash holdings $m$ as well as a persistent rise in the nominal interest rate $i$ (Fig. $3 \mathrm{H}, \mathrm{C}, \mathrm{G}$, and $\mathrm{E}$ ).

The macroeconomic effects of a $1 \%$ innovation to the $O M R$ are mainly driven by the increased amount of government bonds outstanding, as can be seen from Fig. 4B. An increase in the open market ratio $b_{t+1} / s_{t}$ for given reserves $s_{t}$ is associated with an increase in bond holdings $b_{t+1}$ of private agents on the one hand and, by the assumption of a balanced budget (28), a decline in high-powered money $h_{t}$ on the other hand. In order to induce agents to hold more bonds and less cash $m$, the market clearing interest rate on bonds $i$ has to increase. Consequently, the portfolio structures of households and banks change. Households substitute their bond holdings $b^{h}$ for capital $k$, leading to a persistent decline in the capital stock (Fig. 3H and B). Households also reduce cash holdings $m$ as the opportunity costs of real balances increase with higher nominal rates $i$ (compare equations 9 and 10).

In order to understand the adjustments in the balance sheets of the banks, we need to study the behavior of firms' loan demand. Firms must obtain loans from banks in order to pay labor and capital, see (13). An increasing interest rate $i$ on bonds also translates into a higher lending rate $i^{l}$ according to (27). By increasing the marginal costs of capital $k$ and labor $l$, firms decrease their labor and their capital demand as can be seen from the inspection of the firms' first-order conditions (15)-(16). As a consequence, equilibrium employment $l$ and capital $k$ fall (Fig. 3J and $\mathrm{H}$ ). In addition, the real wage $w$ and the interest rate $r$ decline as well (Fig. 3F). For constant productivity, the fall in both inputs results in a fall of total loans $z$ and output $y$. Consequently, real reserves $s$ which are a constant fraction of loans decline as well (Fig. 3C), but only very slightly compared to the rise in government bonds (Fig. 3B).

In period 1, households anticipate the rise in interest rates on bonds in the subsequent periods. As a consequence, they reduce their investment expenditures already in period 1, while they increase their consumption and their real balance holdings (Fig. 3G and H). ${ }^{25}$ Simultaneously, they decrease their labor supply according to (5)-(6). Firms, on the other hand, increase their labor demand as the interest rate declines. In the labor market equilibrium of period 1, wages increase and employment (and, hence, output) falls. The respective responses in real terms are only of a small magnitude, since prices are totally flexible.

An obvious shortcoming of the model's specification with flexible prices is that shocks to the $O M R$ mainly translate into a substitution of open market securities for real balances and capital in the agents portfolio. While changes in the asset holdings are substantial, the impact on real activity and, therefore, on intermediated funds is of much smaller magnitude. As can be observed in Fig. 1 and 2, this response pattern is not in accordance with estimated impulse response functions. In particular, our estimates in section 2 indicate that, following a shock to the $O M R$, non-borrowed reserves decline and open market securities rise roughly by the same percentage change. In order to provide a more realistic specification of the

\footnotetext{
${ }^{25}$ Notice that households increase their demand of bonds in both period 1 and subsequent periods. As in the first period, however, the supply of bonds does not increase, the interest rate on bonds $i$ falls. In subsequent periods, the supply of bonds increases resulting in a rise of the interest rate $i$.
} 
A. Output y

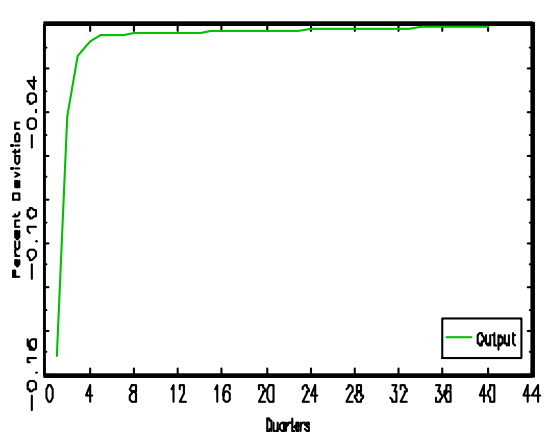

D. Inflation pi

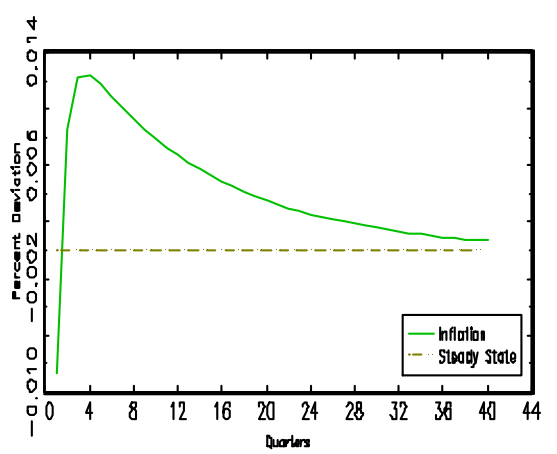

G. Real Balance $m$ and High Powered Money $h$

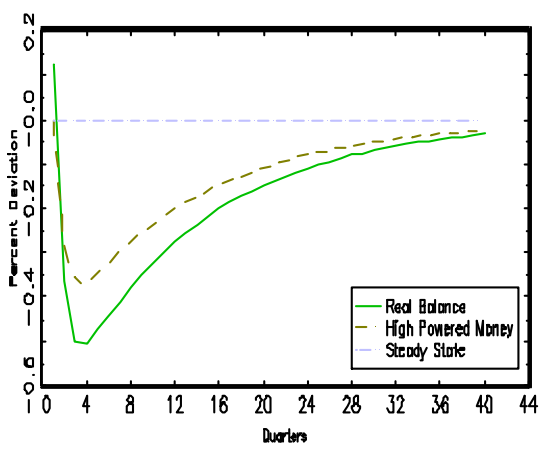

J. Employment I and Investment $e$

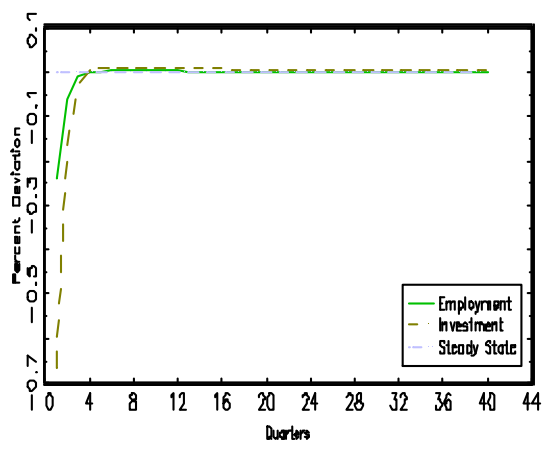

B. Totol Bands $\mathrm{b}$ and $\mathrm{HH}$ Bonds bh

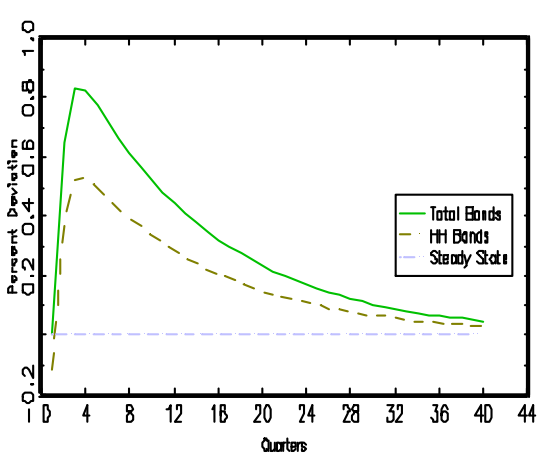

E. Return on Bonds $i$ and Lending Rote il

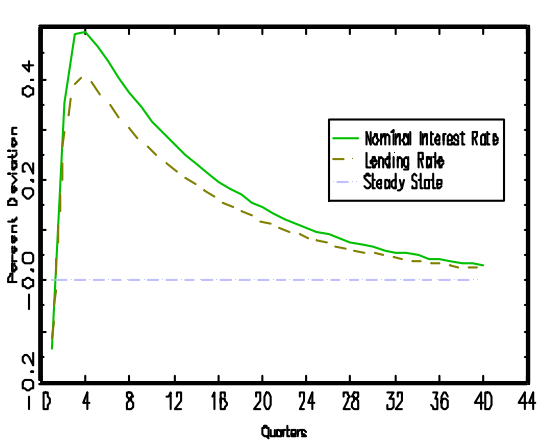

H. Copital Stock k and Consumption c

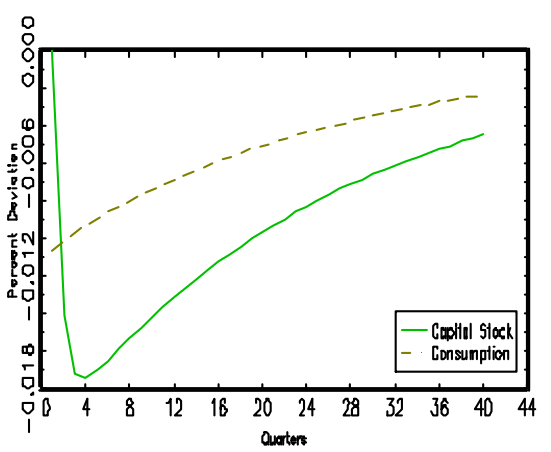

K. Retail Profits omega_r and Mark-up x

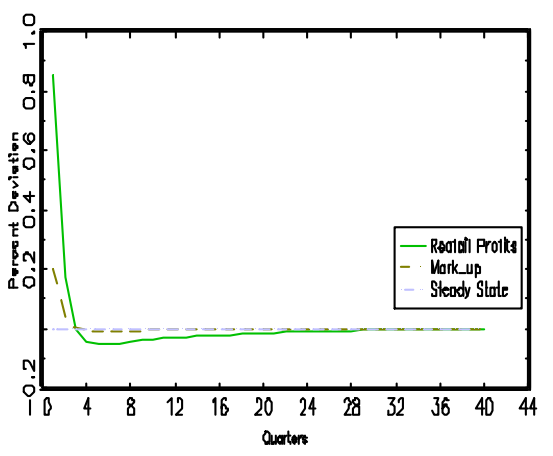

C. Reserves $\mathrm{s}$

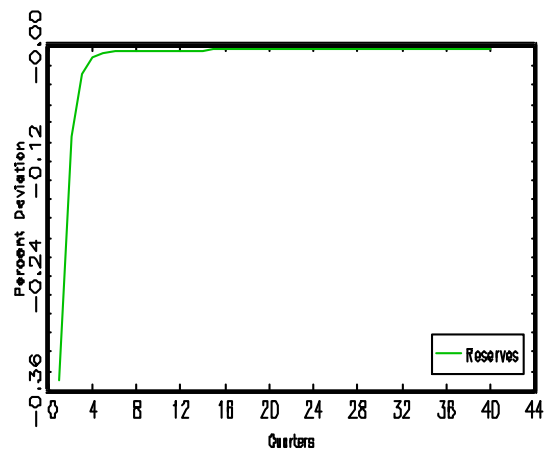

F. Wage w and Return on Capital r

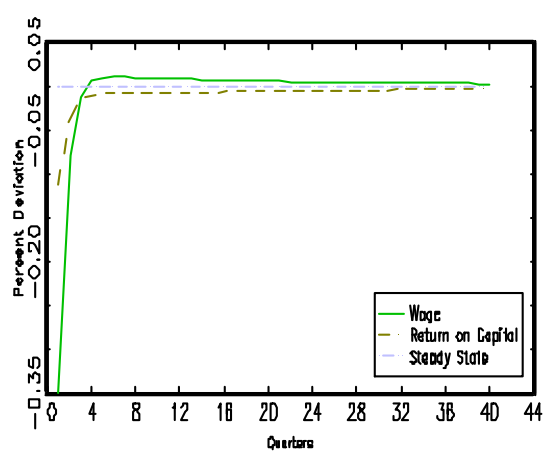

I. Loons z

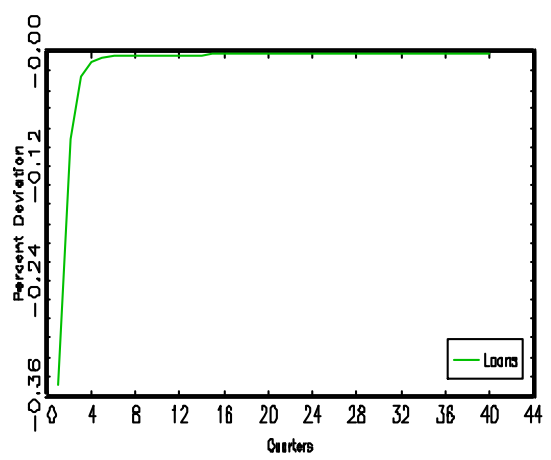

L. Real Return on Bonds it

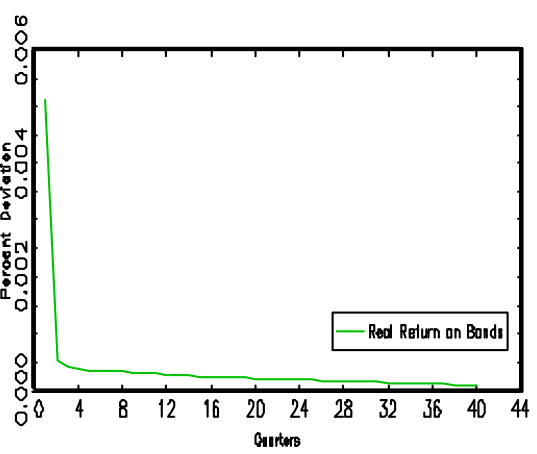

Figure 4: Response to a $1 \%$ OMR Innovation with $\phi=0.75$ (Deviations in \%) 
A. Output y

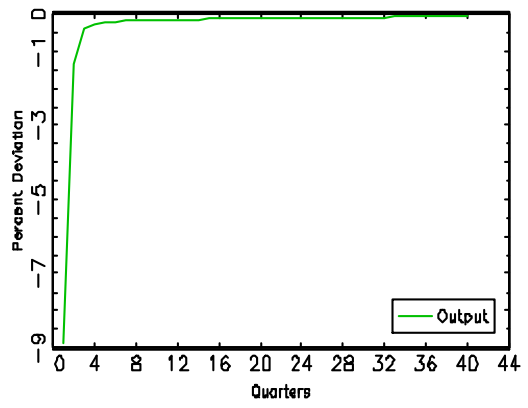

D. Nominal Interest $i$ and Lending Rate

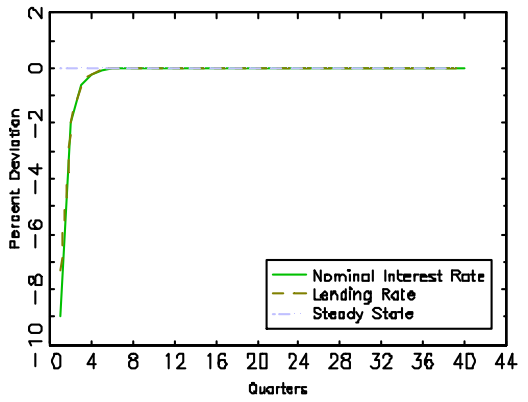

A. Loons z

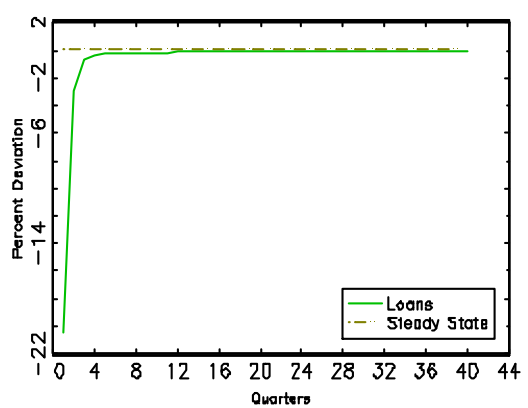

B. High Powered Money $h$ and Capital k

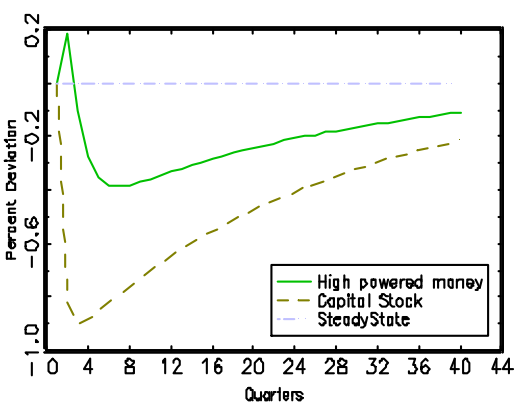

F. Real Balance $m$ and Mark-up $x$

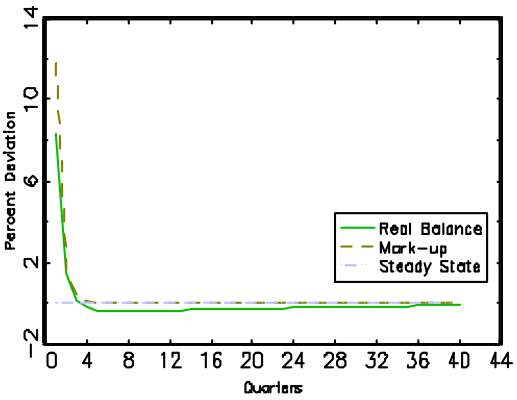

c. Employment I and Wage w

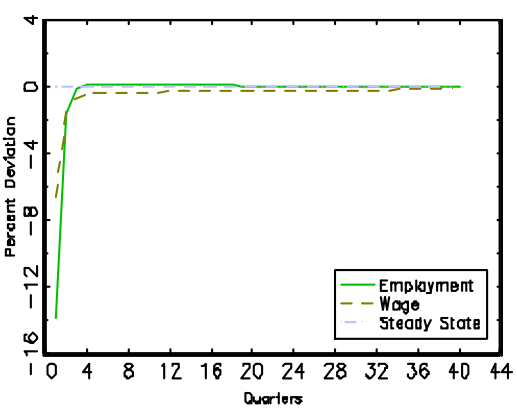

C. Inflation pi and Consumption c

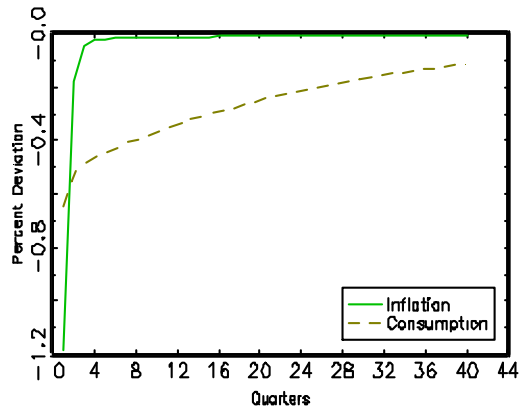

G. Reserves s

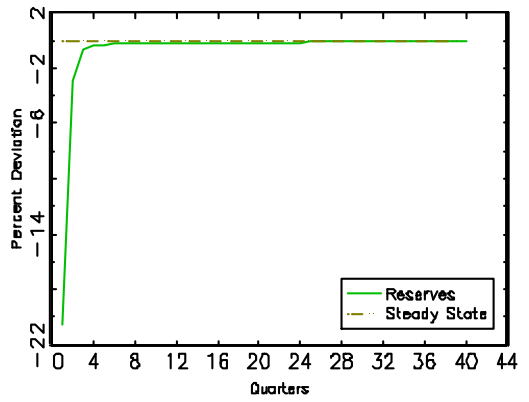

E. Return on Capital $r$ and Investment

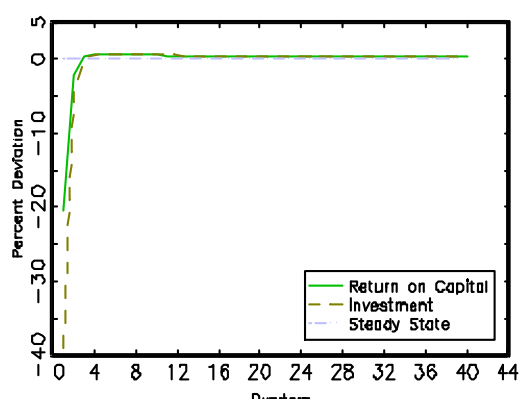

Figure 5: Responses to a 1\% MGR Innovation with $\phi=0.75$ (Deviations in \%)

economy, we introduce a nominal rigidity in our model and assume that retailers set their prices in a staggered way. In an economy with rigid prices, the impact of monetary impulses on both aggregate demand and real activity are markedly augmented.

Fig. 4 displays the responses of macroeconomic variables to the $O M R$ shock for sticky prices, $\phi=0.75$. All responses are substantially magnified when price staggering is introduced. Considering the retail sector, a fraction $1-\phi$ of the retailers changes its prices every period. In response to a fall in aggregate demand in period 1, these retailers decrease their prices $p$ and, initially, the inflation rate $\pi$ falls (Fig. 4D). The smaller the fraction $1-\phi$, the less pronounced is the decline of the inflation rate $\pi$ (compare with Fig. 3D). The fraction $\phi$ of retailers increases its prices by the steady state inflation rate $\bar{\pi}$ and, consequently, sells less output $y_{i t}$. As the price of the wholesale good $p^{W}$ falls sharply, the mark-up $x$ increases (Fig. $4 \mathrm{~K})$. The rise of the mark-up ratio induces a downward pressure on factor remuneration, as both the equilibrium real wage $w$ and the real interest rate $r$ are a negative function of the mark-up. Consequently, aggregate production exhibits a strong decline in period 1 in response to the contractionary monetary impulse (Fig. 4A).

For the analysis of the inflation rate and the real interest rate on bonds $r^{b}$, consider the 
Fisher equation: $1+r^{b}=\left(1+i_{t}\right) \pi_{t}^{-1}$. Comparing the latter with the household's optimality condition on capital accumulation (8), the real return on bonds $r^{b}$ must equal the return on capital $r$, if we abstract from adjustment costs of capital. Assume that the real return on capital falls and the nominal interest rate on bonds rises after a monetary tightening. Then, the inflation rate must rise in order to fulfill the Fisher equation. As displayed in Fig. 3D and $4 \mathrm{D}$, the latter result also holds in the case of positive adjustment costs of capital. In contrast to the case without adjustment costs, however, our benchmark model generates a rising real rate of return on bonds (Fig $4 \mathrm{~L}$ ), well in accordance with the empirical evidence presented in section 2. ${ }^{26}$ During the first five quarters following an $O M R$ shock, the response of the real return bonds (measured as the nominal return on T-bills minus the inflation rate), is positive, as can be seen from Fig. 2.

In sum, in the model with price staggering, monetary aggregates, interest rates, and real variables behave almost as observed empirically and presented in section 2, with only one exception. Empirically, it can be found that profits decline after a contractionary monetary policy (see Fig. 2). As it is also commonly found in other models of sticky prices, ${ }^{27}$ profits of price setters (which equal the retailers' profits ${ }^{r}$ ) increase in our model as the mark-up increases during a monetary contraction and, in particular, the effect of the rise in the markup $x$ is initially more pronounced than the effect of a fall in the output $y$ (Fig. 4K). This picture changes in the case of flexible prices $\phi=0$, where retail profits decline persistently after a monetary contraction (see Fig. $3 \mathrm{H}) \cdot{ }^{28}$

The impulse responses to a $M G R$ shock are different from the ones to an $O M R$ shock. Fig. 5 presents various responses to a contractionary $M G R$ shock. Following a contraction of nominal money supply $H$, households receive less transfers $\tau$. Consequently, household consumption and investment demand fall. The price behavior of the retailers is similar to the one in the model with $O M R$ shocks. As demand falls, the flexible price retailers cut their prices $p$ and the sticky price retailers reduce their output demand. Consequently, inflation falls and the mark-up increases (Fig $5 \mathrm{C}$ and F). Both real factor prices, the wage rate $w$ and the interest rate $r$, decline with a higher mark-up $x$. As the supply of bonds $B=B^{h}+B^{b}$ is exogenous, the fall in the return on capital and the inflation rate results in a fall of the nominal interest rate $i$ (Fig. 5D). The household adjusts its portfolio by reducing capital holdings $k$ and bond holdings $B^{h}$, while it even increases real cash holdings $m$ (Fig. 5F).

The most important difference between the model with an $O M R$ shock and the model with a $M G R$ shock is the counterfactual behavior of the nominal interest rate implied by the latter model. The rate of return on bonds $i$ and the lending rate $i^{l}$ decrease in response to a monetary injection. This behavior of nominal interest rates is inconsistent with empirical evidence on the responses of nominal interest rates to various monetary policy measures as presented in section 2 . Therefore, we consider the $O M R$ specification of the monetary policy to be more appropriate for our model. ${ }^{29}$

\footnotetext{
${ }^{26}$ In the case of the flexible price model, the real interest rate on bonds only rises in the first period, when the inflation rate falls. Contrary to our benchmark model, the flexible price model predicts that real interest rates on bonds are lower than the steady state value in the subsequent periods (Fig. 3L).

${ }^{27}$ See, e.g., Christiano et al. (1997).

${ }^{28}$ Bank profits ${ }_{t}^{b}=(1 / \theta-1) i_{t} s_{t}$ (not illustrated), which are only a small fraction of total profits, display a persistent rise after a transitory contraction.

${ }^{29}$ In models of limited participation, a decrease of money growth only results in a lasting rise of nominal interest rates if both financial markets are subject to frictions and households face adjustment costs of their asset portfolio (Chari et al., 1995).
} 


\subsection{Persistence and the Amplitude of Output Responses}

As shown in the previous subsection, the qualitative behavior of the variables in the model with $O M R$ shocks is robust to variations in the price regime, whereas the magnitudes of the responses, in particular output, change substantially. In this section, we perform an analysis of output responses concentrating on the effects of price rigidity and adjustment costs of capital. Fig. 6 displays the responses of output to an $O M R$ shock of $1 \%$ with adjustment $\operatorname{costs}\left(\Phi^{\prime \prime} / \Phi^{\prime}=-0.25\right)$ and without adjustment costs $(\Phi(e / k) \cdot k=e)$ on the one hand and to a $M G R$ shock of $1 \%$ with adjustment costs on the other hand. Obviously, the amplitude of the output responses to an $O M R$ shock declines with more flexible prices, whereas the persistence rises.

First, consider the amplitude of the output response functions. The maximum deviation of output from its steady state value in response to a $1 \% O M R$ innovation is $0.152 \%$ and $0.0125 \%$ for $\phi=0.75$ and $\phi=0$, respectively. The estimated output response function to an $O M R$ shock, as presented in section 2, displays a maximum deviation of output equal to $0.073 \%$ (Fig. 1B), lying within the range of the values computed for our model with an $O M R$ shock. The responses to $M G R$ shocks are generally found to have a much stronger amplitude than the responses to $O M R$ shocks. In our benchmark case characterized by a price rigidity of $\phi=0.75$, the contemporaneous output deviates by $8.89 \%$ from its steady state value in response to a $1 \%$ shock to money growth. Contemplating Fig. 1A and Fig. 1B, a $1 \%$ deviation of the M1 growth rate in response to innovations of both monetary policy measures ( FF RATE, OMR) is associated with an approximate rise of real GDP by $1.3 \%{ }^{30}$ A similar value is obtained for the empirical standard deviation of output relative to M1 growth. In particular, our estimate for the latter number amounts to $\widehat{\sigma}^{y} / \widehat{\sigma}^{m g}=1.45$. From these observations, we conclude that the output response to a $M G R$ shock as implied by our model is inconsistent with the empirical evidence.

Regarding the persistence of the impulse responses, we find that $O M R$ shocks produce more persistent responses than $M G R$ shocks regardless of the degree of price rigidity. Fig. 6 shows that, in case of a monetary injection, output immediately recovers for all degrees of price rigidity, whereas the output responses to $O M R$ shocks display a marked persistence, especially for more flexible prices. As displayed in the second row of Fig 6, the output response to an $O M R$ shock remains persistent, even if we abstract from adjustment costs of capital. ${ }^{31}$ The findings in Fig. 6 are supported by our estimated autocorrelations of simulated output series. ${ }^{32}$ In our benchmark case with $\phi=0.75$ and with (without) adjustment costs of capital, the autocorrelation of output is moderately positive amounting to $\rho^{y}=0.27$ $\left(\rho^{y}=0.17\right)$. For comparison, the empirical autocorrelation of output amounts to $\widehat{\rho}^{y}=0.86$ in the US economy. ${ }^{33}$ Notice, however, that our model is only simulated for an isolated shock to monetary policy, whereas the additional consideration of a technology shock generally results in a higher first-order autocorrelation of output. In the case of a $M G R$ shock, the estimate

\footnotetext{
${ }^{30}$ Similar response ratios cannot reasonably be calculated for innovations to broad monetary aggregates, as empirical output impulse responses to M0 and M1 growth shocks are found to be insignificant, see ,e.g., Christiano et al. (1999) or Fig. A1D in Appendix A.

${ }^{31}$ For sticky price models with monetary injections, Chari et al. (1996) show that it is necessary to assume adjustment costs in order to generate persistent output effects.

${ }^{32}$ Autocorrelations are estimated from the simulated output series which have been logged and detrended using the Hodrick-Prescott filter.

${ }^{33}$ The statistics have been computed using logged and detrended time series of output (GDP92) during 1960-99.
} 
OMR: phi $=0.75$

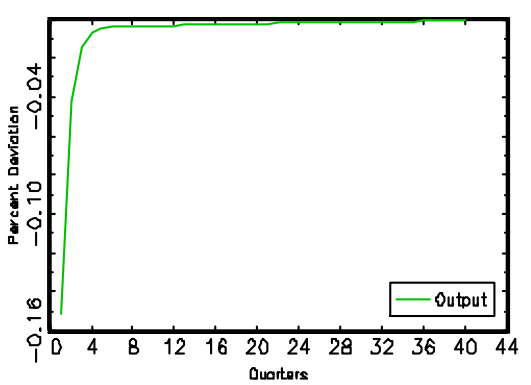

OMR: No Adjustment Costs, phi $=0.75$ :

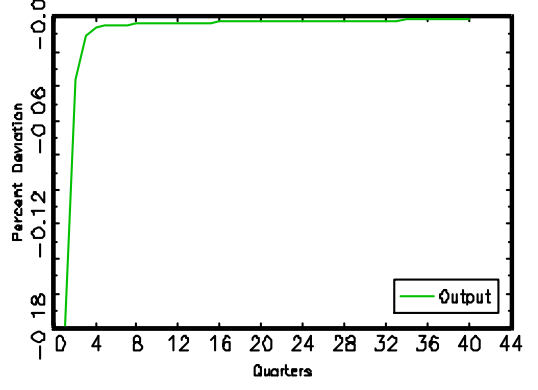

M1GR: phi $=0.75$

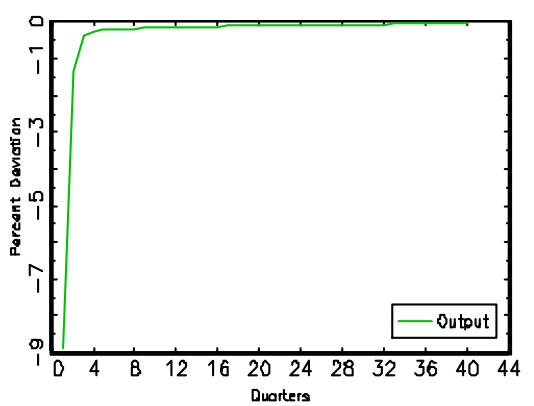

OMR: $\mathrm{phi}=0.5$

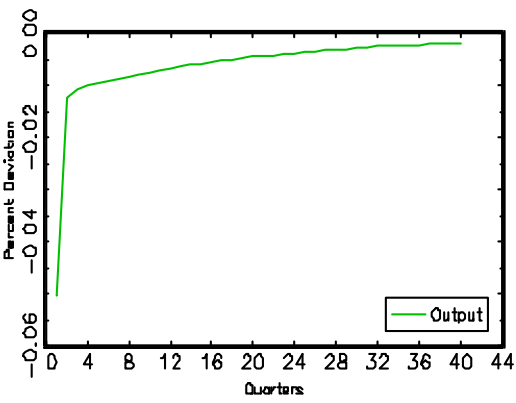

OMR: No Adjustment Costs, phi $=0.5$

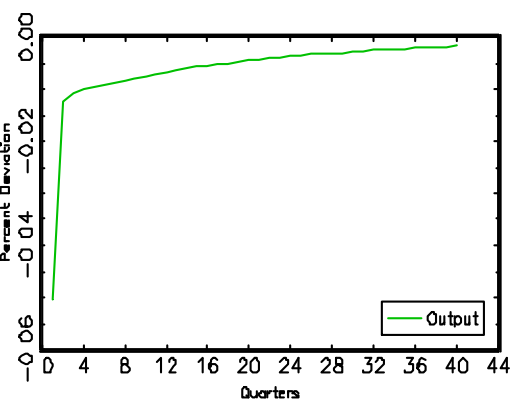

M1GR: phi $=0.5$

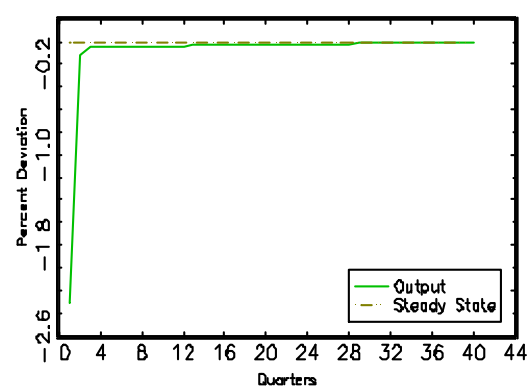

OMR: phi $=0$

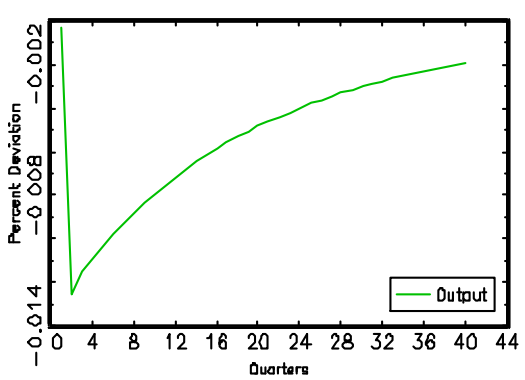

OMR: No Adjustment Costs, phi $=0$

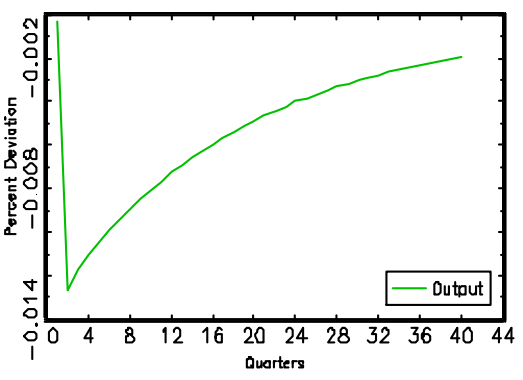

MIGR: phi $=0.25$

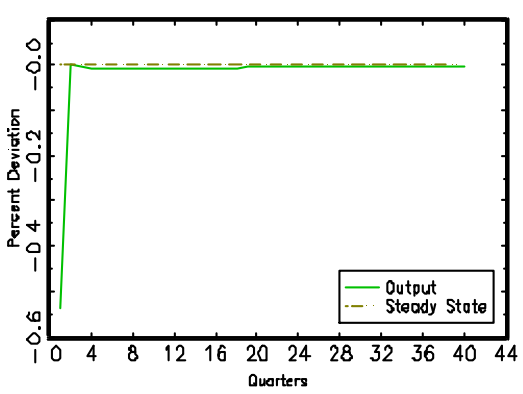

Figure 6: Output Responses to MGR and OMR Innovations

for output autocorrelation $\left(\rho^{y}=0.01\right)$ is insignificant for our benchmark specification. With higher degrees of price flexibility, we find that the autocorrelation of output rises. For example, we estimated a value of 0.65 for the autocorrelation of output in the model with an $O M R$ shock, adjustment costs of capital, and flexible prices.

From this discussion, we observe that there is a trade-off between the amplitude and the persistence of the output response depending on the degree of price rigidity in our model. Surprisingly, the response of output is less persistent in the case of sticky prices. The reason for our result is simple. After period 2, the output response to an $O M R$ shock is mainly driven by the persistent rise in the interest rate. Therefore, the output response pattern to an $O M R$ shock are almost identical after the 2 nd period for flexible prices $(\phi=0)$ and rigid prices $(\phi=0.75)$. However, in the case of sticky prices, we also observe a strong decline of production in period 1 , induced by a fall in aggregate demand. The initial output response is much lower if all retailers are able to adjust prices instantaneously. As a consequence, if prices are more sticky, the output response in the first period relative to the output response in later periods rises and we observe a jump in the output response function in period 2. For this reason, persistence as measured by the first-order autocorrelation of output declines. 


\subsection{Second Moments Properties of Money-related Series}

In this subsection, we discuss the second moment properties of money-related series simulated with our theoretical model for both specifications of monetary policy and compare them with their empirical counterparts. We start the analysis of this simulation experiment with the discussion of selected correlations for the cases of a pure monetary policy shock in order to isolate the effects stemming from the particular specification of our monetary policy rule. We apply the standard treatment of data for the computation of the statistics in the real business cycle literature. In particular, the moments reported in Tables 3, 4, and A1 are computed from Hodrick-Prescott filtered quarterly time series. Table 3 presents the contemporaneous correlations of variables with output and the monetary policy variable for both US data and our benchmark economy with a shock to open market operations. The correlations as implied by our theoretical model are computed for an economy with flexible $(\phi=0)$ and staggered prices $(\phi=0.75)$, respectively. Table 4 presents the corresponding correlations for the economy with innovations to the technology level as an additional shock.

In the subsequent analysis, we focus on correlations of financial variables, which are displayed in the upper part of each table. The last two columns in Table 3 present the correlations of financial variables with both monetary policy measures in the case of an $O M R$ shock and flexible prices. The sign and the magnitude of all correlations, except for those of bank loans, are in good accordance with the empirical correlations presented in column 3 and 4 . In the case of monetary injections, we find that the empirical correlations between various variables cannot be replicated (see Table A1, column 9 in Appendix D). E.g., instead of negative values, we find nearly perfect positive correlations between money growth on the one hand and interest rates, inflation, and the velocity on the other hand. Furthermore, contrary to empirical evidence, the model with monetary injections predicts a negative money growth correlation with both output and the stock of high powered money. These results support the view that the consideration of $O M R$ shocks rather than of $M G R$ shocks is more adequate in the model with flexible prices.

While the flexible price model with $O M R$ shocks performs well with regard to the correlations between financial variables and monetary policy measures, the correlations with output are inconsistent with the empirical ones. For example, instead of moderate positive correlations, we find that output is almost perfectly negatively correlated with interest rates, bonds, and the velocity. These shortcomings, together with the small standard deviation of the simulated output series (approx. 1/18 of the empirical value), indicate that the consideration of a nominal rigidity might improve the model's performance. Accordingly, column five of Table 3 shows that the correlations between output and financial variables as implied by our model with staggered prices are clearly closer to the empirical ones than the respective correlations implied by the flexible price model. At the same time, the model's performance with regard to the remaining correlations is also improved. A similar effect due to the introduction of sticky prices cannot be observed in the case of a $M G R$ shock. Even though the correlation between output and money growth displays the correct sign for $\phi=0.75$ (contrary to the case $\phi=0$ ), many output and money growth correlations still display disproportionate large values and wrong signs (compare column 6 and 7 of Table A1 in Appendix D). Additionally, we obtain an unrealistically high standard deviation of the simulated output series in the model with exogenous money growth, which reflects the strong contemporaneous output response to monetary injections described in the previous subsection. 
Table 3: Correlations for Open Market Operations' Shocks

\begin{tabular}{|c|c|c|c|c|c|c|c|c|c|}
\hline & \multirow{2}{*}{\multicolumn{3}{|c|}{$\begin{array}{c}\text { Moments of US Series } \\
(1960: 1-1999: 1)\end{array}$}} & \multicolumn{6}{|c|}{ Moments of Simulated Series } \\
\hline & & & & \multicolumn{3}{|c|}{$\phi=0.75$} & \multicolumn{3}{|c|}{$\phi=0$} \\
\hline & Output & MGR & OMR & Output & MGR & OMR & Output & MGR & OMR \\
\hline \multicolumn{10}{|c|}{ FINANCIAL SERIES: } \\
\hline FFRATE & 0.33 & -0.44 & 0.58 & 0.45 & -0.22 & 0.38 & -0.99 & -0.47 & 0.41 \\
\hline PRLOANR & 0.37 & -0.40 & 0.49 & - & - & - & - & - & - \\
\hline TBILLR & 0.32 & -0.47 & 0.57 & - & - & - & - & - & - \\
\hline M1 & 0.11 & 0.20 & -0.60 & -0.23 & 0.32 & -0.58 & 0.99 & 0.50 & -0.47 \\
\hline M1GR & -0.11 & 1 & -0.25 & 0.19 & 1 & -0.42 & 0.45 & 1 & -0.34 \\
\hline VELOC & 0.24 & -0.29 & 0.73 & 0.53 & -0.19 & 0.28 & -0.99 & -0.47 & 0.40 \\
\hline OMR & -0.04 & -0.25 & 1 & -0.65 & -0.42 & 1 & -0.45 & -0.34 & 1 \\
\hline NBRES & -0.19 & 0.24 & -0.78 & 0.99 & 0.23 & -0.65 & 0.49 & 0.50 & -0.74 \\
\hline OMPAP & -0.20 & -0.18 & 0.86 & 0.28 & -0.26 & 0.54 & -0.99 & -0.45 & 0.42 \\
\hline DEBT & 0.49 & -0.15 & 0.24 & - & - & - & - & - & - \\
\hline BLOANS & 0.48 & -0.10 & 0.13 & 0.99 & 0.23 & -0.65 & 0.49 & 0.51 & -0.74 \\
\hline \multicolumn{10}{|c|}{ NONFINANCIAL SERIES: } \\
\hline GDP92 & 1 & -0.11 & -0.04 & 1 & 0.19 & -0.65 & 1 & 0.45 & -0.45 \\
\hline GDPDF & -0.68 & -0.06 & 0.34 & 0.24 & 0.51 & -0.51 & 0.57 & 0.53 & -0.48 \\
\hline EMPL & 0.83 & -0.23 & 0.22 & 0.99 & 0.18 & -0.62 & 0.99 & 0.49 & -0.48 \\
\hline INFL (CPI) & 0.36 & -0.26 & 0.35 & 0.64 & -0.19 & 0.17 & -0.78 & -0.27 & -0.20 \\
\hline PROF & 0.65 & -0.28 & -0.08 & -0.99 & -0.17 & 0.62 & -0.99 & -0.47 & 0.39 \\
\hline
\end{tabular}

Note: The moments are computed from logged and Hodrick-Prescott filtered data. Series not expressed in percentage terms have been logged first. The statistics for the theoretical models are computed as averages from $500 \times 150$ simulations.

Up to this point, we can conclude that our sticky price model generates reasonable values for most of the financial correlations in the case of an $O M R$ shock. A closer look at the correlations between output on the one hand and the components of our shock measure $(N B R E S, O M P A P, O M R)$ as well as the level and the growth rate of the monetary aggregate $(M 1, M 1 G R)$ on the other hand suggests that some empirical moments cannot solely be replicated by monetary shocks. This conclusion is also supported by the correlations of the nonfinancial variables in the lower half of Table 3. Except of inflation, these variables exhibit correlations with output and the monetary policy measures which are inconsistent with the empirical ones. In order to both reconcile the behavior of our model with theses observations and to replicate the empirical standard deviation of output (the standard deviation of output generated by our model amounts to approximately $3 / 5$ of the empirical value), we also consider a second, non-monetary shock. Hence, we extend the simulation experiment and allow for innovations to the technology level. As already mentioned in section 3, we assume that the innovations to the technology level and the innovations to the monetary policy measure are independently distributed. The standard deviation of the technology innovations is chosen in order to replicate the empirical standard deviation of output with our benchmark model. The correlations for the series simulated with both shocks are presented in Table 4.

As can be seen in column 5 of Table 4, the additional consideration of technology shocks leads to a slight improvement concerning the correlations between the monetary aggregates 
and output. ${ }^{34}$ The reduced correlations between output on the one hand and money, money growth, and the open market ratio on the other hand are more favorable than in the case of pure money shocks, whereas the output correlations with non-borrowed reserves and open market papers remain inconsistent with the empirical ones. Turning to the lower half of Table 4, the correlations between the nonfinancial variables and output are in accordance with the empirical correlations except for total profits. ${ }^{35}$ Furthermore, the addition of technology shocks leads to insignificant correlations between money growth and the nonfinancial variables. Comparing these correlations with their empirical counterparts, the latter also being either insignificant or moderately negative, we find that the consideration of technology shocks helps to improve the model's performance.

Table 4: Correlations for Open Market Operations' and Technological Shocks

\begin{tabular}{|c|c|c|c|c|c|c|c|c|c|}
\hline & \multirow{2}{*}{\multicolumn{3}{|c|}{$\begin{array}{c}\text { Moments of US Series } \\
\text { (1960:1-1999:1) }\end{array}$}} & \multicolumn{6}{|c|}{ Moments of Simulated Series } \\
\hline & & & & \multicolumn{3}{|c|}{$\phi=0.75$} & \multicolumn{3}{|c|}{$\phi=0$} \\
\hline & Output & MGR & OMR & Output & MGR & OMR & Output & MGR & OMR \\
\hline \multicolumn{10}{|c|}{ FINANCIAL SERIES: } \\
\hline FFRATE & 0.33 & -0.44 & 0.58 & 0.36 & -0.38 & 0.40 & -0.08 & -0.31 & 0.69 \\
\hline PRLOANR & 0.38 & -0.40 & 0.49 & - & - & - & - & - & - \\
\hline TBILLR & 0.32 & -0.47 & 0.57 & - & - & - & - & - & - \\
\hline M1 & 0.11 & 0.20 & -0.60 & -0.14 & 0.44 & -0.57 & 0.07 & 0.34 & -0.73 \\
\hline M1GR & -0.11 & 1 & -0.25 & 0.03 & 1 & -0.20 & -0.03 & 1 & -0.28 \\
\hline VELOC & 0.24 & -0.29 & 0.73 & 0.51 & -0.35 & 0.32 & -0.05 & -0.31 & 0.69 \\
\hline OMR & -0.04 & -0.25 & 1 & -0.28 & -0.20 & 1 & 0.07 & -0.28 & 1 \\
\hline NBRES & -0.19 & 0.24 & -0.78 & 0.90 & 0.06 & -0.34 & 0.19 & 0.41 & -0.68 \\
\hline OMPAP & -0.20 & -0.18 & 0.86 & 0.16 & -0.40 & 0.55 & 0.02 & -0.28 & 0.70 \\
\hline DEBT & 0.49 & -0.15 & 0.24 & - & - & - & - & - & - \\
\hline BLOANS & 0.48 & -0.10 & 0.13 & 0.90 & 0.06 & -0.34 & 0.19 & 0.41 & -0.68 \\
\hline \multicolumn{10}{|c|}{ NONFINANCIAL SERIES: } \\
\hline GDP92 & 1 & -0.11 & -0.04 & 1 & 0.03 & -0.29 & 1 & -0.03 & 0.07 \\
\hline GDPDF & -0.68 & -0.06 & 0.34 & -0.35 & 0.16 & -0.39 & -0.37 & 0.27 & -0.60 \\
\hline EMPL & 0.83 & -0.23 & 0.22 & 0.95 & 0.03 & -0.28 & 0.91 & 0.09 & -0.21 \\
\hline INFL (CPI) & 0.36 & -0.26 & 0.35 & 0.75 & -0.07 & 0.14 & -0.47 & 0.06 & 0.17 \\
\hline PROF & 0.65 & -0.28 & -0.08 & -0.85 & -0.03 & 0.26 & 0.72 & -0.24 & 0.53 \\
\hline
\end{tabular}

Note: The moments are computed from logged and Hodrick-Prescott filtered data. Series not expressed in percentage terms have been logged first. The statistics for the theoretical models are computed as averages from $500 \times 150$ simulations.

Notice, however, that our model generates moderately negative correlations between our

\footnotetext{
${ }^{34}$ The corresponding values for the case of a MGR shock are presented in column 4 of Table A1 in Appendix D. It is obvious by the inspection of these values that the results of the latter specification remains unsatisfactory even after adding technological shocks.

${ }^{35}$ The behavior of profits has been attracting increasing attention in recent work on monetary business cycle analysis. E.g., Christiano and Eichenbaum (1997a) conclude that the counterfactual implication for profits is the key failure of sticky price models. In fact, for our benchmark calibration, both firms' profits and total profits (which simply equal firms' profits plus bank profits) are anticyclical, whereas firms' profits (and, similarly, total profits) become procyclical in the case of flexible prices $(\phi=0)$, and bank profits are procyclical independent of the degree of price stickiness.
} 
shock variable, the open market ratio, on the one hand and output, prices, and employment on the other hand. This result accords well with our finding in subsection 4.1 that a monetary contraction leads to a decline in output, prices, and employment. Similarly in section 2, we, empirically, found a contraction in the exogenous component of monetary policy to imply a negative response of output, prices, and employment as well (compare Fig. 1-3). Our empirical contemporaneous correlations, however, do not reflect this kind of causality. In particular, employment and prices are positively correlated with the open market ratio and negatively correlated with money growth. The lacking ability of standard monetary business cycle models to replicate these empirical observations has also been noticed by Cooley and Hansen (1998), among others.

One possible reason for the divergence of the simulated correlations from their empirical counterparts is our treatment of monetary policy. Like in most monetary business cycle models, monetary policy is exogenous, while in reality the monetary authority changes its policy depending on the state of the economy. ${ }^{36}$ In section 2 we follow Christiano et al. (1996) and identify output, prices, and, optionally, employment, as arguments of a monetary policy function. Hence, we implicitly assume that changes in these variables induce contemporaneous movements in the monetary policy variable. Given this specification of the policy function, an expansion of these variables results in a monetary tightening, e.g. a rise in the open market operations. In order to reconcile the model's behavior with empirical observations on the $O M R$ (or, similarly, the money growth) correlations with non-financial variables, we consider the endogenization of monetary policy as a worthwhile area of future research. ${ }^{37}$

In sum, our theoretical monetary model with an $O M R$ shock on the one hand and a $M G R$ shock on the other hand cannot account for the empirical second moments of all money-related variables. Our results, however, indicate that the sticky price model with monetary policy specified as innovations to open market operations is able to reproduce most monetary features of the business cycle more successfully than the model with a monetary policy measure in the form of exogenous money growth. In our benchmark model with an $O M R$ shock, private agents react to an open market operation by reducing investment expenditures, consumption, and cash holdings. Money is endogenous and, as a consequence, the extremely high comovement between money growth and most financial and nonfinancial variables in the case of monetary injections breaks down. We, therefore, carefully conclude that monetary business cycle models with $O M R$ shocks and endogenous monetary aggregates are a promising alternative to standard business cycle models with exogenous money growth.

\footnotetext{
${ }^{36}$ See Christiano et al. (1997b) for a discussion of the appropriateness to specify monetary policy as an exogenous process rather that highly reactive to the state of the economy in the analysis of quantitative general equilibrium models.

${ }^{37}$ As proposed and analyzed by Sargent (1984) one may abstract from specifying the monetary authority's objective function explicitly and rather use historical data to develop a statistical model of the feedback rule used by the government. In a similar vain, Bernanke et al. (1998), Rotemberg and Woodford (1998), and McGrattan (1999) use Taylor rules for the specification of the monetary policy (see footnote 3 ).
} 


\section{Conclusion}

In most industrialized countries, open market operations are the dominant instrument of monetary policy. What is more natural then as to specify monetary policy as the exchange of securities for reserves between the monetary authority and the banks? In this paper we identify monetary policy shocks as innovations to the ratio of outstanding open market papers to non-borrowed reserves of banks. Our empirical analysis based upon observations from the US economy during 1960-99 provides strong evidence for the usefulness of this measure. In particular, we observe a significant decline in output, monetary aggregates, and price indices as well as a significant rise in short-term interest rates in response to a monetary tightening.

We examine a business cycle model where monetary policy is conducted by open market operations. We apply the identical monetary policy shock measure as in the empirical analysis. We add several features which we judge to be important aspects in order to enhance empirical relevance of the theoretical model. In particular, we introduce adjustment costs of capital, price staggering, and financial intermediation. The transmission of monetary policy shocks is mainly driven by portfolio adjustments of private agents who change the composition of real balances, bonds, and physical capital. We assess the performance of the model to reproduce impulse response functions of our empirical analysis and second moment properties of US time series. First, we find that most impulse responses of our model to an open market operations' shock are qualitatively equal to their empirical counterparts. Particularly, real and nominal interest rates on bonds rise and output, aggregate demand, factor prices as well as monetary aggregates decline persistently in response to a monetary tightening. Considering the output response to an open market shock, our model with sticky rather than flexible prices is able to replicate the response amplitude of the corresponding estimates taken from the data. Second, we compare contemporaneous correlations of US time series with the correlations implied by simulations of our model. While the model generates reasonable contemporaneous correlations between various financial variables and monetary policy measures, it displays difficulties to replicate correlations of non-financial variables. The monetary policy measure presented in this paper is shown to be a promising alternative to traditional measures. For more ambituous simulation purposes, the latter result suggests the consideration of a monetary policy rule where the monetary authority also reacts to the state of the economy. 


\section{Appendix}

\section{Appendix A: Impulse Responses of VARs with Various Policy Measures}

Figure A1: Impulse Responses to One S.D. INSTR Innovations \pm S.E.

\section{A. INSTR $=$ OMPAP}
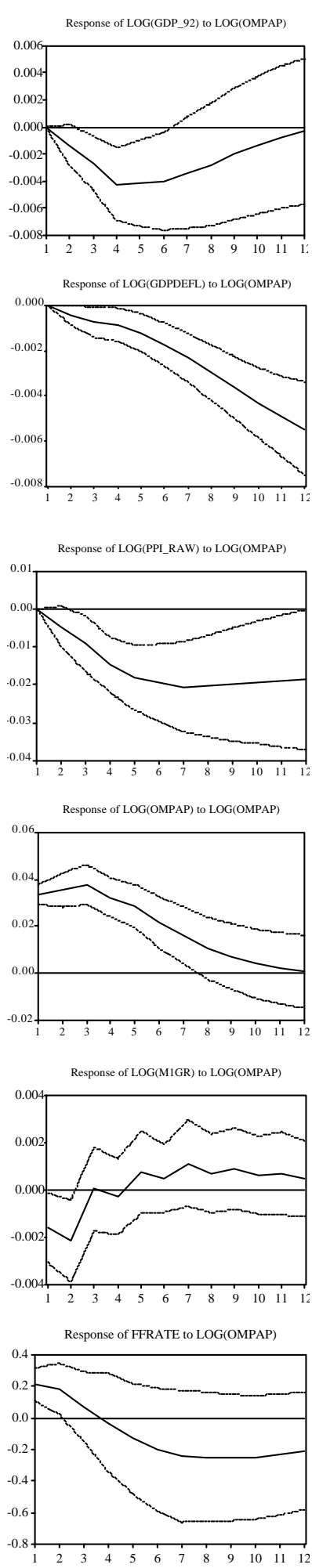

B. INSTR $=-$ NBRES
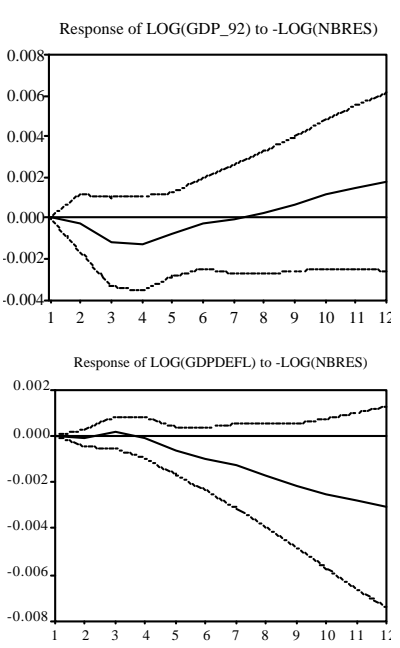

Response of LOG(PPI_RAW) to -LOG(NBRES)

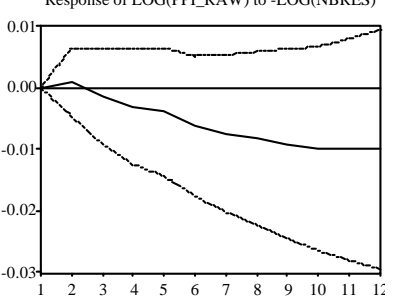

Response of -LOG(NBRES) to -LOG(NBRES)
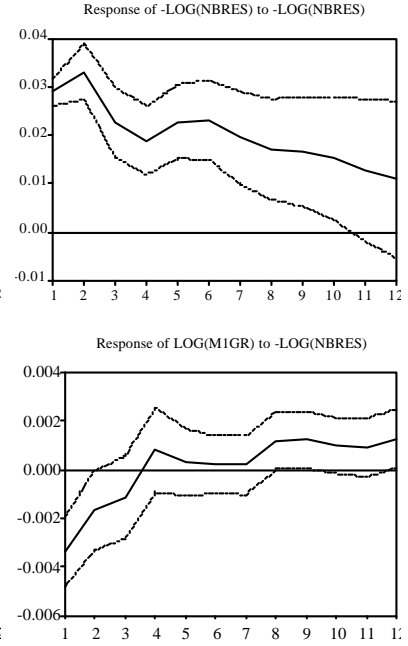

Response of FFRATE to -LOG(NBRES

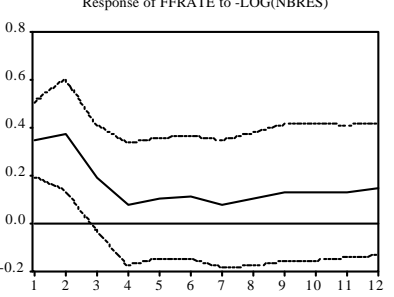

C. INSTR $=-\mathrm{NBRX}$

D. INSTR $=-\mathrm{M} 1 \mathrm{GR}$
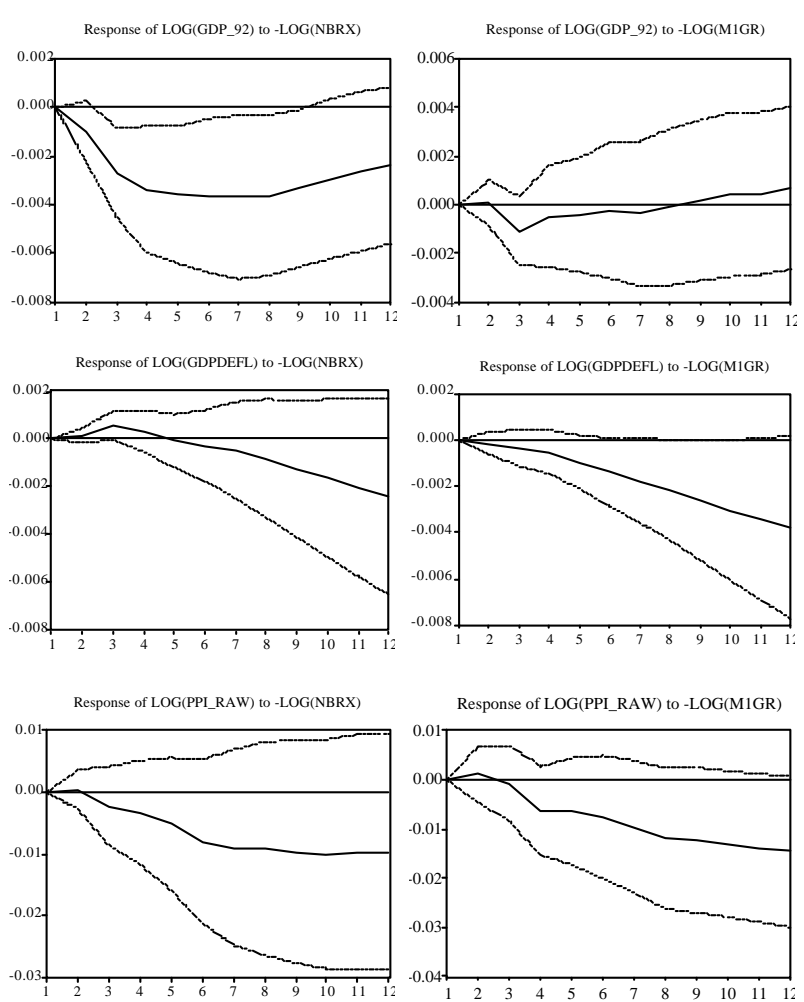

Response of -LOG(NBRX) to -LOG(NBRX)

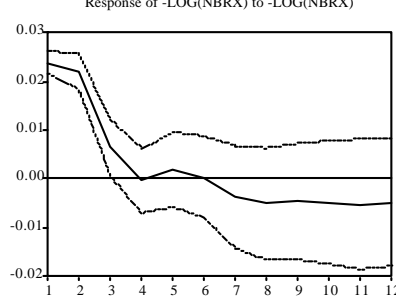

Response of LOG(MIGR) to -LOG(NBRX)
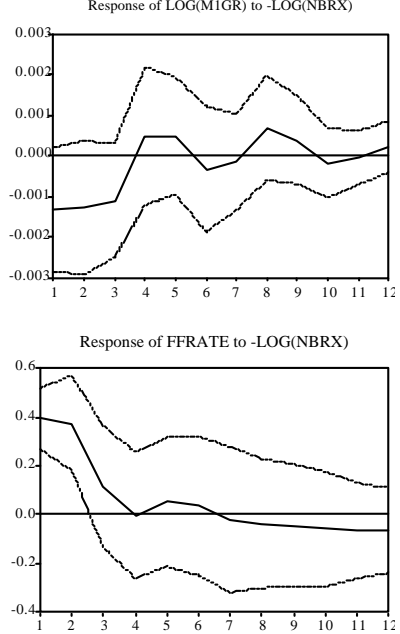

Response of LOG(PPI_RAW) to -LOG(MIGR)

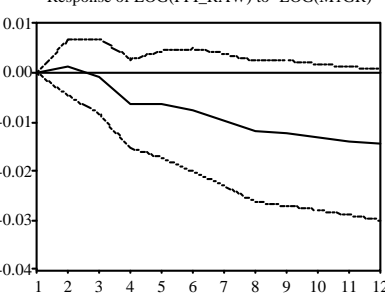

Response of -LOG(MIGR) to-LOG(MIGR

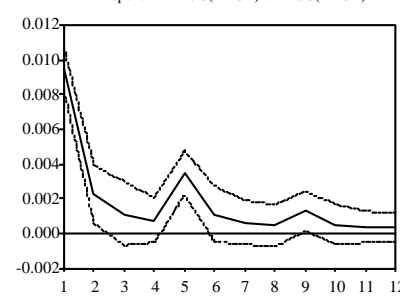

Response of LOG(M2GR) to -LOG(M1GR)

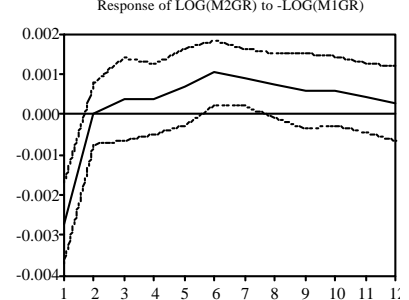

Response of FFRATE to -LOG(M1GR)

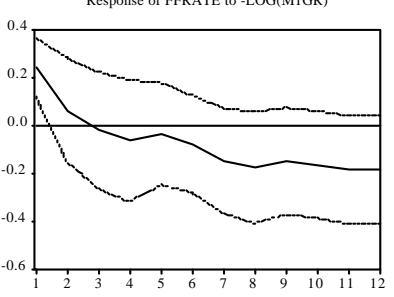

Note: The impulse response functions are computed from the 5-variable VARs: (GDP_92, GDPDEFL, $P P I \quad R A W, I N S T R, D)$, with INSTR $\in\{O M P A P, N B R E S, M 1 G R)$ and $D \in\{M 1 G R, M 2 G R)$. In the case of $I N S T R=N B R X$, we apply a 6-variable VAR including GDP_92, GDPDEFL, PPI_RAW, TORES, NBRES, D. 


\section{Appendix B: Linearized Model for Open Market Operations' Shocks}

State variables: $k_{t}, \tilde{h}_{t} \equiv \frac{H_{t}}{p_{t-1}}, \tilde{b}_{t} \equiv \frac{B_{t}}{p_{t-1}}$

Costates: $\pi_{t}, \lambda_{t}, q_{t}$

Control variables: $c_{t}, l_{t}, e_{t}, w_{t}, r_{t}, x_{t}, i_{t}^{l}, i_{t}, z_{t}, s_{t}, b_{t}^{b}, b_{t}^{h}, m_{t}$

Exogenous states: $a_{t}, \mu_{t}^{o m r}$

Dynamic Equations:

$$
\begin{aligned}
& \hat{k}_{t+1}-\left(1-\phi^{\prime} \frac{e}{k}\right) \hat{k}_{t}=\phi^{\prime}(.) \frac{e}{k} \hat{e}_{t} \\
& -\hat{q}_{t}+\hat{\lambda}_{t+1}-\hat{\lambda}_{t}+\beta\left(1-\phi^{\prime} \frac{e}{k}\right) \hat{q}_{t+1}+\beta \phi^{\prime \prime}\left(\frac{e}{k}\right)^{2} \hat{k}_{t+1}=-\frac{\beta}{q} r \hat{r}_{t+1}+\beta \phi^{\prime \prime}\left(\frac{e}{k}\right)^{2} \hat{e}_{t+1} \\
& -\hat{x}_{t}=E\left[\frac{\phi}{(1-\phi)(1-\beta \phi)}\left(\widehat{\pi}_{t}-\beta \widehat{\pi}_{t+1}\right)\right] \\
& \tilde{b}_{t+1}=\hat{s}_{t}+\hat{\mu}_{t} \\
& \hat{\lambda}_{t}-\hat{\lambda}_{t+1}+\hat{\pi}_{t+1}=\frac{i}{1+i} \hat{i}_{t+1} \\
& \tilde{h} \tilde{h}_{t+1}+\tilde{b} \tilde{b}_{t+1}-\frac{\tilde{h}}{\pi} \tilde{h}_{t}-(1+i) \frac{\tilde{b}}{\pi} \tilde{b}_{t}+\frac{\tilde{h}}{\pi} \hat{\pi}_{t}+(1+i) \frac{\tilde{b}}{\pi} \hat{\pi}_{t}=\frac{i \tilde{b}}{\pi} \hat{i}_{t}-\psi_{z} z \hat{z}_{t}
\end{aligned}
$$

Contemporaneous equations:

$$
\begin{gathered}
\hat{c}_{t}=-\hat{\lambda}_{t} \\
\hat{w}_{t}=-\hat{\lambda}_{t} \\
\hat{w}_{t}+\hat{x}_{t}+\alpha \hat{l}_{t}+\frac{i^{l}}{1+i^{l}} \hat{i}_{t}^{l}=\alpha \hat{k}_{t}+\hat{a}_{t} \\
\hat{r}_{t}+\hat{x}_{t}-(1-\alpha) \hat{l}_{t}+\frac{i^{l}}{1+i^{l}} \hat{i}_{t}^{l}=-(1-\alpha) \hat{k}_{t}+\hat{a}_{t} \\
\frac{\phi^{\prime \prime}}{\phi^{\prime}} \frac{e}{k} \hat{e}_{t}=\frac{\phi^{\prime \prime}}{\phi^{\prime}} \frac{e}{k} \hat{k}_{t}-\hat{q}_{t} \\
\hat{a}_{t}+\alpha k_{t}=\frac{c}{y} \hat{c}_{t}+\frac{e}{y} e_{t}-(1-\alpha) \hat{l}_{t} \\
0=-i^{i} \hat{i}_{t}^{l}+i \hat{i}_{t}+\psi_{z z} z \hat{z}_{t} \\
w l\left(\hat{w}_{t}+\hat{l}_{t}\right)+r k \hat{r}_{t}-z \hat{z}_{t}=-r k \hat{k}_{t} \\
0=-s / \theta \hat{s}_{t}+z \hat{z}_{t} \\
b^{b} \hat{b}_{t}^{b}+s \hat{s}_{t}=0 \\
\frac{\tilde{b}}{\pi}\left(\tilde{b}_{t}-\hat{\pi}_{t}\right)=b^{h} \hat{b}_{t}^{h}+b^{b} \hat{b}_{t}^{b} \\
\frac{\tilde{h}}{\pi}\left(\tilde{h}_{t}-\hat{\pi}_{t}\right)=s \hat{s}_{t}+m \hat{m}_{t} \\
-\hat{\lambda}_{t}=\widehat{m}_{t}+\widehat{i}_{t}
\end{gathered}
$$




\section{Appendix C: Selected Correlations of Simulated Series}

Table A1: Correlations for Money Growth Shocks (with $\sigma^{a}>0$ and $\sigma^{a}=0$ )

\begin{tabular}{|c|c|c|c|c|c|c|c|c|}
\hline & \multicolumn{2}{|c|}{ Moments of US Series } & \multicolumn{6}{|c|}{ Moments of Simulated Series } \\
\hline & & & \multirow{2}{*}{\multicolumn{2}{|c|}{$\begin{array}{c}\sigma^{a}>0 \\
\phi=0.75\end{array}$}} & \multicolumn{4}{|c|}{$\sigma^{a}=0$} \\
\hline & \multicolumn{2}{|c|}{$(1960: 1-1999: 1)$} & & & \multicolumn{2}{|c|}{$\phi=0.75$} & \multicolumn{2}{|c|}{$\phi=0$} \\
\hline & Output & MGR & Output & MGR & Output & MGR & Output & MGR \\
\hline \multicolumn{9}{|c|}{ FINANCIAL SERIES: } \\
\hline FFRATE & 0.33 & -0.44 & 0.99 & 0.96 & 0.99 & 0.96 & -0.99 & 0.99 \\
\hline PRLOANR & 0.38 & -0.40 & - & - & - & - & - & - \\
\hline TBILLR & 0.32 & -0.47 & - & - & - & - & - & - \\
\hline M1 & 0.11 & 0.20 & -0.37 & -0.26 & -0.38 & -0.27 & 0.29 & -0.32 \\
\hline M1GR & -0.11 & 1 & 0.93 & 1 & 0.94 & 1 & -0.99 & 1 \\
\hline VELOC & 0.24 & -0.29 & 0.99 & 0.94 & 0.99 & 0.95 & -0.99 & 0.99 \\
\hline OMR & -0.04 & -0.25 & - & - & - & - & - & - \\
\hline NBRES & -0.19 & 0.24 & -0.95 & -0.91 & -0.95 & -0.90 & 0.56 & -0.59 \\
\hline OMPAP & -0.20 & -0.18 & -0.95 & -0.91 & -0.95 & -0.90 & 0.56 & -0.59 \\
\hline DEBT & 0.49 & -0.15 & - & - & - & - & - & - \\
\hline BLOANS & 0.48 & -0.10 & -0.95 & -0.91 & -0.95 & -0.90 & 0.56 & -0.59 \\
\hline \multicolumn{9}{|c|}{ NONFINANCIAL SERIES: } \\
\hline GDP92 & 1 & -0.11 & 1 & 0.93 & 1 & 0.94 & 1 & -0.99 \\
\hline GDPDF & -0.68 & -0.06 & -0.33 & -0.14 & -0.36 & -0.18 & 0.14 & -0.17 \\
\hline EMPL & 0.83 & -0.23 & 0.99 & 0.92 & 0.99 & 0.93 & 0.99 & -0.99 \\
\hline INFL (CPI) & 0.36 & -0.26 & 0.99 & 0.95 & 0.99 & 0.94 & -0.89 & 0.90 \\
\hline PROF & 0.65 & -0.28 & -0.84 & -0.87 & -0.82 & -0.82 & -0.99 & 0.99 \\
\hline
\end{tabular}

Note: The moments are computed from logged and Hodrick-Prescott filtered data. Series not expressed in percentage terms have been logged first. The statistics for the theoretical models are computed as averages from $500 \times 150$ simulations.

\section{Appendix D: Data Sources}

FEDERAL RESERVE BOARD, FLOW OF FUNDS: Total Open Market Papers Outstanding: FL893169175 (OMPAP), Credit Market Instruments Holdings of the Monetary Authority: FL14002105 (DEBT_FR), Debt Outstanding Total Nonfinancial Sectors: FL384104005 (DEBT_NF), Debt Outstanding Domestic Financial Sector: FL794104005 (DEBT_F, with DEBT=DEBT_NF+DEBT_F), Non-Borrowed Reserves (NBRES), Total Reserves (TOTRES), Required Reserves (REQ_RES).

IMF FINANCIAL STATISTICS: Federal Funds Rate (FFRATE), Treasury Bill Rate (TBILL_R), Bank Prime Loan Rate (PRLOAN_R), M1 Seasonally Adjusted (M1), M2 Seasonally Adjusted (M2), Demand Deposits (DMDEP).

OECD MAIN INDICATORS: Corporate Profits: 421013NSA (PROFITS), CPI All Items SA: 425241K (CPI), GDP 1992 Prices SA: 421037NSA (GDP_92), GDP Implicit Price Level SA: 421051KSA (GDPDEFL), Bank Loans + Investments SA: 426131DSA (BLOANS), PPI Crude Goods Raw Materials: 425023K (PPI_RAW), Employment Civilian SA: 424023KSA (EMPL), Standardized Unemployment Rate SA: 424117DSA (UNEMPL_R). 


\section{References}

Bernanke, B., and A. Blinder, 1992, The Federal Funds Rate and the Channels of Monetary Transmission, American Economic Review, vol. 82, 901-921.

Bernanke, B.S., M. Gertler, and S. Gilchrist, 1998, The Financial Accelerator in a Quantitative Business Cycle Framework, NBER Working Paper, no. 6455.

Bernanke, B.S., and M. Woodford, 1997, Inflation Forecasts and Monetary Policy, Journal of Money, Credit, and Banking, vol. 29, 653-684.

Calvo, G., 1983, Staggered Prices in a Utility-Maximizing Framework, Journal of Monetary Economics, vol. 12, 383-398.

Chari, V.V., L.J. Christiano, and M. Eichenbaum, 1995, Inside Money, Outside Money, and Short-Term Interest Rates, Journal of Money, Credit and Banking, vol. 27, 135486 .

Chari, V.V., P.J. Kehoe, and E.R. McGrattan, 1996, Sticky Price Models of the Business Cycle: Can the Contract Multiplier Solve the Persistence Problem?, Research Department Staff Report 217, Federal Reserve Bank of Minneapolis.

Cho, J.-O., and T. Cooley, 1995, The Business Cycle with Nominal Contracts, Economic Theory, vol. 6, 13-33.

Christiano, J.L., 1991, Modeling the Liquidity Effect of a Money Shock, Federal Reserve Bank of Minneapolis Quarterly Review, vol. 15, 3-34.

Christiano, J.L., and M. Eichenbaum, 1992, Liquidity Effects and the Monetary Transmission Mechanism, American Economic Review, vol. 82, 346-53.

Christiano, J.L., and M. Eichenbaum, 1995, Liquidity Effects, Monetary Policy, and the Business Cycle, Journal of Money, Credit, and Banking, vol. 27, 1113-36.

Christiano, J.L., M. Eichenbaum, and C.L. Evans, 1996, The Effects of Monetary Policy Shocks: Evidence from the Flow of Funds, Review of Economics and Statistics, vol. $78,16-35$.

Christiano, J.L., M. Eichenbaum, and C.L. Evans, 1997a, Sticky price and Limited Participation Models of Money: A Comparison, European Economic Review, vol. 41, 1201-49.

Christiano, J.L., M. Eichenbaum, and C.L. Evans, 1997b, Modeling Money, paper presented at the Meeting of the Society for Economic Dynamics, Oxford, 1997.

Christiano, J.L., M. Eichenbaum, and C.L. Evans, 1999, Monetary Policy Shocks: What Have We Learned and to What End?, in: M. Woodford and J.B. Taylor (eds.), Handbook of Macroeconomics, Amsterdam: North-Holland.

Cooley, T.F., and G.D. Hansen, 1989, The Inflation Tax in a Real Business Cycle Model, American Economic Review, vol. 79, 733-48. 
Cooley, T.F., and G.D. Hansen, 1995, Money and the Business Cycle, in: Cooley, T.F. (ed.), Frontiers of Business Cycle Research, Princeton University Press, Princeton, $175-216$.

Cooley, T.F., and G.D. Hansen, 1998, The Role of Monetary Shocks in Equilibrium Business Cycle Theory: Three Examples, European Economic Review, vol. 42, 605617.

Cooley, T., and V. Quadrini, 1999, A Neoclassical Model of the Phillips Curve Relation, Journal of Monetary Economics, vol. 44, 165-193.

Diaz-Giménez, J., E.C. Prescott, T. Fitzgerald, and F. Alvarez, 1992, Banking in Computable General Equilibrium Economies, Journal of Economic Dynamics and Control, vol. 16, 533-59.

Eichenbaum, M., 1992, Comments on 'Interpreting the Macroeconomic Time Series Facts: The Effects of Monetary Policy' by Christopher Sims, European Economic Review, vol. $36,1001-1011$.

Fuerst, T.S., 1992, Liquidity, Loanable Funds, and Real Activity, Journal of Monetary Economics, vol. 29, 3-24.

Jeanne, O., 1998, Generating Real Persistent Effects of Monetary Policy: How much Nominal Rigidity Do We Really Need?, European Economic Review, vol. 42, 1009-1032.

King, R.G., and A.L. Wolman, 1996, Inflation Targeting in a St. Louis Model of the 21st Century, Federal Reserve of St. Louis Review, vol. 78, 83-111.

Lucas, R.E. Jr., 1990, Liquidity and Interest Rates, Journal of Economic Theory, vol. 50, 237-264.

Lucas, R.E. Jr., and N.L. Stokey, 1987, Money and Interest in a Cash-in-Advance Economy, Econometrica, vol. 55, 491-513.

McGrattan, E.R., 1999, Predicting the Effects of Federal Reserve Policy in a Sticky-Price Model: An Analytical Approach, Research Department Working Paper 598, Federal Reserve Bank of Minneapolis.

Ohanian, L.E., and A.C. Stockman, 1994, Short-run Effects of Money When Some Prices are Sticky, Federal Reserve Bank of Richmond Economic Review Quarterly, vol. 80, $1-23$.

Ohanian, L.E., A.C. Stockman, and L. Kilian, 1995, The Effects of Real and Monetary Shocks with Some Sticky Prices, Journal of Money, Credit, and Banking, vol. 27, 1209-1234.

Rotemberg, J., 1996, Prices, Output and Hours: An Empirical Analysis based on a Sticky Price Model, Journal of Monetary Economics, vol. 27, 505-533.

Rotemberg, J., and M. Woodford, 1997, An Optimization-based Econometric Framework for the Evaluation of Monetary Policy, NBER Macroeconomics Annual, Cambridge, Mass.: MIT Press 297-346. 
Rotemberg, J., and M. Woodford, 1998, Interest Rate Rules in an Estimated Sticky Price Model, NBER Working Paper, no. 6618.

Sargent, T.J., 1984, Autoregressions, Expectations, and Advice, American Economic Review, vol. $74,408-15$.

Schreft, S., and B. Smith, 1998, The Effects of Open Market Operations in a Model of Intermediation and Growth, Review of Economic Studies, vol. 65, 519-550.

Sims, C.A., 1986, Are Forecasting Models Usable for Policy Analysis? Federal Reserve Bank of Minneapolis Quarterly Review, 3-16.

Sims, C.A., 1992, Interpreting the Macroeconomic Time Series Facts: The Effects of Monetary Policy, European Economic Review, vol. 36, 975-1000.

Sims, C.A., and T. Zha, 1998, Does Monetary Policy Generate Recessions?, Working Paper 98-12, Federal Reserve Bank of Atlanta.

Strongin, S., 1995, The Identification of Monetary Policy Disturbances: Explaining the Liquidity Puzzle, Journal of Monetary Economics, vol. 34, 463-497.

Yun, Tack, 1996, Nominal Price Rigidity, Money Supply Endogeneity, and Business Cycles, Journal of Monetary Economics, vol. 37, 345-370. 